University of Nebraska - Lincoln

DigitalCommons@University of Nebraska - Lincoln

THE SHORTCOMINGS OF INDETERMINACY IN ARMS CONTROL REGIMES: THE CASE OF THE BIOLOGICAL WEAPONS CONVENTION

Jack M. Beard

University of Nebraska College of Law, jbeard2@unl.edu

Follow this and additional works at: https://digitalcommons.unl.edu/lawfacpub

Beard, Jack M., "THE SHORTCOMINGS OF INDETERMINACY IN ARMS CONTROL REGIMES: THE CASE OF THE BIOLOGICAL WEAPONS CONVENTION" (2007). College of Law, Faculty Publications. 158.

https://digitalcommons.unl.edu/lawfacpub/158

This Article is brought to you for free and open access by the Law, College of at DigitalCommons@University of Nebraska - Lincoln. It has been accepted for inclusion in College of Law, Faculty Publications by an authorized administrator of DigitalCommons@University of Nebraska - Lincoln. 
101 AM. J. INT’L L. 271 (2007).

\title{
THE SHORTCOMINGS OF INDETERMINACY IN ARMS CONTROL REGIMES: THE CASE OF THE BIOLOGICAL WEAPONS CONVENTION
}

\author{
By Jack M. Beard*
}

\section{BIOLOGICAL WEAPONS, INDETERMINACY, AND DESIGN ELEMENTS FOR ARMS CONTROL REGIMES}

In 1972 a historic attempt to create the world's first international legal regime banning the development and possession of an entire class of weapons of mass destruction (WMDs) culminated in the conclusion of the Biological Weapons Convention (BWC). ${ }^{1}$ Crippled by key compromises made by the great powers in pursuit of various self-interested security objectives in the context of the Cold War, the Convention is fundamentally flawed. Although the BWC purports to outlaw the development and possession of all biological weapons, deadlier and more sophisticated biological weapons than were imaginable in 1972 can now be and have been produced, as evidenced in October 2001 by two letters sent to the Capitol Hill offices of Senators Tom Daschle and Patrick Leahy. ${ }^{2}$ These letters reportedly contained threatening notes and a dangerous and sophisticated form of "weapons-grade" anthrax spores. ${ }^{3}$ Even though both the sender of these letters and the source of the anthrax remain unknown, the technical sophistication of the spores led some experts to suggest that the attacker was supported by a U.S. "biodefense" laboratory or an advanced foreign-state-run biological weapons (BW) facility because the spores could not have been produced by an amateur working in his basement. ${ }^{4}$

* Professorial Lecturer, University of California ar Los Angeles; former Associate Deputy General Counsel (International Affairs), U.S. Department of Defense. The views expressed herein are those of the author alone and do not reflect the views of the Department of Defense or the U.S. government. The author appreciatively acknowledges useful comments by David Koplow, Maximo Langer, and Kal Raustiala on earlier drafts. I am also grateful to Scott Dewey and Emmy Levens for research assistance.

${ }^{1}$ Convention on the Prohibition of the Development, Production and Stockpiling of Bacteriological (Biological) and Toxin Weapons and on Their Destruction, Apr. 10, 1972, 26 UST 583, 1015 UNTS 163 [hereinafter $\mathrm{BWC}$.

${ }^{2}$ A study by the Central Intelligence Agency reports that advances in science and technology since 1972 have resulted in genetically engineered pathogens with the ability to cause effects "worse than any disease known to man." John Mintz \& Jody Warrick, U.S. Unprepared Despite Progress, Experts Say, WASH. POST, Nov. 8, 2004, at A1.

${ }^{3}$ A diverse group of sixteen biodefense scientists published a paper describing the Senate anthrax powder as an exceptionally deadly "weapons-grade" version of the bacterium with "high spore concentration, uniform particle size, low electrostatic charge, treated to reduce clumping." Thomas V. Inglesby et al., Anthrax as a Biological Weapon, 2002: Updated Recommendations for Management, 287 J. AM. MED. ASS'N 2236, 2237 (2002); see also Dan Eggen \& Guy Gugliotta, FBI Secretly Trying to Re-create Anthrax from Mail Attacks, WASH. POST, Nov. 2, 2002, at A9 (describing the particles as "astonishingly pure"); Gary Matsumoto, Anthrax Powder: State of the Art? 302 SCIENCE 1492, 1492-94 (2003); Reynolds M. Salerno et al., A BW Risk Assessment: Historical and Technical Perspectives, NONPROLIFERATION REV., Fall/Winter 2004, at 25, 53 n.50.

${ }^{4}$ Although the FBI originally suggested that the anthrax powder could have been produced by a lone amateur working in a basement laboratory, this theory soon came to be regarded as unlikely and was abandoned. Guy 
In addition to the empirical evidence of new "super" biological weapons, the failings of the BWC are further manifested by the growing significance that countries like the United States attach to the BW threat, ${ }^{5}$ allegations by senior U.S. government officials that terrorists and rogue states possess biological weapons, ${ }^{6}$ and contentious review conferences of BWC states parties that have been unable to resolve cheating and compliance concerns. Furthermore, a significant number of states have not yet joined the BWC and few have joined in recent years, prompting statements of concern about its lack of universality. ${ }^{7}$

The BWC is commonly said to have failed because it lacks mandatory transparency measures and a dedicated monitoring organization. ${ }^{8}$ This explanation, which is well grounded in arms control practice, international relations theory, and theoretic game models, posits that a state actor is unlikely to forgo a particular class of weapons permanently unless it receives assurances that adversary states are reciprocally so committed and an effective monitoring regime is in place to ensure against a "surprise defection," that is, cheating. ${ }^{9}$ Perceived security threats and asymmetrical information may generate or enlarge incentives for states to renege, making the Pareto-optimal outcome of mutual disarmament decidedly unstable and transparency a critical factor in ensuring that one state does not take advantage of the other. ${ }^{10}$ In spite of this recognized need for transparency, the states parties to the BWC have been unable to agree on any mandatory transparency measures and the United States in particular has blocked serious efforts at reform. " While the lack of transparency is thus widely cited as a reason for the BWC's

Gugliotta \& Gary Matsumoto, FBI's Theory on Anthrax Is Doubted; Attacks Not Likely Work of 1 Person, Experts Say, WASH. POST, Oct. 28, 2002, at A1. The spores were also reportedly identified as belonging to a highly virulent strain of anthrax used in U.S. biodefense research programs. Eileen Choffnes, Bioweapons: New Labs, More Terror? BULL. ATOM. SCI., Sept./Oct. 2002, at 28. After more than five years without an arrest, however, some FBI officials have reportedly questioned the sophistication of the anthrax powder used in the attacks. Allan Lengel \& Joby Warrick, FBI Is Casting a Wider Net in Anthrax Attacks, WASH. POST, Sept. 25, 2006, at $\mathrm{A} 1$.

${ }^{5}$ Four of the top five "Nightmares for Disaster Planning" developed by the Department of Homeland Security involve BW attacks. Eric Lipton, U.S. Lists Possible Terror Attacks and Likely Toll, N.Y. TIMES, Mar. 16, 2005, at A1. The perceived BW threat also figured prominently-and erroneously-in the arguments of senior U.S. officials justifying an invasion of Iraq. E.g., Steven R. Weisman, Powell, in U.N. Speech, Presents Case to Show Iraq Has Not Disarmed, N.Y. TIMES, Feb. 6, 2003, at A1.

${ }^{6}$ President Bush has flatly stated that "[r] ogue states and terrorists possess these weapons and are willing to use them." George W. Bush, Statement on Strengthening the International Regime Against Biological Weapons, 37 WEEKLY COMP. PRES. DOC. 1580, 1580 (Nov. 5, 2001).

${ }^{7}$ The Secretary-General: Message to the Fifth Review Conference of the States Parties to the Biological Weapons Convention (Nov. 19, 2001), available at <http://www.opbw.org> [hereinafter BWC Web site].

${ }^{8}$ The lack of verification mechanisms has been criticized and debated by BWC states parties since at least 1986, resulting in intensive, but unsuccessful, efforts by the "Ad Hoc Group" from 1994 to 2001 to develop a protocol to the BWC that would have established various legally binding declaration, visit, and continuous monitoring procedures. See infra notes 77-84 and corresponding text.

${ }^{9}$ Looking at the role that information can play in strategic interactions between states acting with mixed motives, legal scholars have used the well-known Prisoners' Dilemma and other models drawn from noncooperative game theory to gain valuable insights into the meaning and function of arms control agreements generally. See, e.g., Kenneth W. Abbott, "Trust But Verify": The Production of Information in Arms Control Treaties and Other International Agreements, 26 CORNELL INT'L L.J. 1 (1993).

${ }^{10}$ ARTHUR A. STEIN, WHY NATIONS COOPERATE: CiRCUMSTANCE AND CHOICE IN INTERNATIONAL RELATIONS 142 (1990). Transparency is also linked to rationalist explanations of state compliance with international law that rely on reputational concerns. See Kal Raustiala, Compliance and Effectiveness in International Regulatory Cooperation, 32 CASE W. RES. J. INT'L L. 387, 402 (2000).

11 The U.S. government abruptly ended a seven-year-long reform in July 2001 by effectively ending consideration of the BWC draft protocol. See infra notes 80-84 and corresponding text. 
lack of success, this article argues that another, equally important factor contributes to the ineffectiveness of the BWC and other disarmament or arms control regimes that operate in environments where member states perceive their security to be threatened: the use of indeterminate $^{12}$ language in key provisions, a phenomenon that is sometimes characterized as a dimension of "soft law."

There is substantial disagreement among legal scholars about the definition, status, and role of soft law; ${ }^{13}$ however, many argue that it considerably influences the behavior of states and displays significant advantages over "hard law" in different areas of international practice. ${ }^{14}$ The term "soft law" is often used to denote principles, standards, or arrangements of a nonlegally binding nature. ${ }^{15}$ But the absence of formal legal obligation is arguably only one characteristic of a continuum of softness: the term "soft law" is also used by scholars to refer to hortatory language ${ }^{16}$ and to imprecise, ambiguous, vague, or otherwise indeterminate formulations, ${ }^{17}$ even when found in legally binding agreements like the BWC. ${ }^{18}$ Key structural deficiencies in international agreements, such as the failure of the BWC to provide for any mandatory mechanisms to enhance transparency and enforcement, are also sometimes associated with soft law when the elements of an international agreement

\footnotetext{
${ }^{12}$ I use the term "determinacy" to encompass concepts of both precision and clarity and I refer to determinate provisions as those that clearly convey their message, communicate their intent, and help "shape that intent into a specific situational command." Thomas M. Franck, Legitimacy in the International System, 82 AJIL 705, 725
} (1988).

${ }^{13}$ Commentators have long suggested that "soft law" can manifest itself in an "infinite variety" of forms. See R. R. Baxter, International Law in Her "Infinite Variety," 29 INT'L \& COMP. L.Q. 549 (1980). Sufficient variations of soft law now exist for scholars to suggest that there is "no acepted definition." Dinah L. Shelton, Normative Hierarchy in International Law, 100 AJIL 291, 319 (2006).

${ }^{14}$ See Andrew T. Guzman, A Compliance-Based Theory of International Law, 90 CAL. L. REV. 1823, 1880 (2002) ("[M] any instruments that are not considered 'law' under the classical definition have a substantial impact on the behavior of states."); Geoffrey Palmer, New Ways to Make International Environmental Law, 86 AJIL 259, 269 (1992) (describing soft law solutions as "useful steps on a longer journey" and the point where "international law and international politics combine to build new norms"); Anne-Marie Slaughter et al., International Law and International Relations Theory: A New Generation of Interdisciplinary Scholarship, 92 AJIL 367 (1998) (emphasizing the advantages of nonbinding soft law in the context of international governance and the generation of norms by supranational institutions and their dissemination by nongovernmental organizations); David Weissbrodt \& Muria Kruger, Norms on the Responsibilities of Transnational Corporations and Other Business Enterprises with Regard to Human Rights, 97 AJIL 901, 914 (2003) (noting the impact of soft law on the interpretation of treaties and on the establishment of customary international law in areas such as human rights).

${ }^{15}$ Shelton, supra note 13, at 319.

${ }^{16}$ Edith Brown Weiss, Introduction to INTERNATIONAL COMPLIANCE WITH NON-BINDING ACCORDS 1, 3 (Edith Brown Weiss ed., 1997) [hereinafter INTERNATIONAL COMPLLANCE].

${ }^{17}$ See Kenneth W. Abbott \& Duncan Snidal, Hard and Soft Law in International Governance, 54 INT'L ORG. 421,422 (2000) (arguing that "'soft law' begins once legal arrangements are weakened along one or more of the dimensions of obligation, precision, and delegation"); Prosper Weil, Towards Relative Normativity in International Law? 77 AJIL 413,414-15 n.7 (1983) (stating that "[i]t would seem better to reserve the term 'soft law' for rules that are imprecise and not really compelling"); Shelton, supra note 13 , at 319 (noting that " $[\mathrm{c}]$ he term 'soft law' is also sometimes employed to refer to the weak, vague, or poorly drafted content of a binding instrument"). Unlike hortatory or purely aspirational language, however, such indeterminate provisions retain a legally binding character and are not soft law in the sense that an adjudicative body with jurisdiction would decline to apply them on the grounds that they do not entail a legal obligation whose content can be ascertained by resort to established interpretive techniques.

${ }^{18}$ FRIEDRICH KRATOCHWIL, RULES, NORMS, AND DECISIONS 200-01 (1989); Christine Chinkin, Normative Developments in the International Legal System, in COMMITMENT AND COMPLIANCE: THE ROLE OF NONBINDING NORMS IN THE INTERNATIONAL LEGAL SYSTEM 21, 25-26 (Dinah L. Shelton ed., 2000) [hereinafter COMMITMENT AND COMPLIANCE]. 
are viewed as a whole. ${ }^{19}$ While these different variants of soft law are often merged to such an extent that some scholars appear to find little reason to distinguish between them, ${ }^{20}$ others argue that such a merger impedes the study of law's relative influence on state behavior because it conflates the legally binding nature of agreements with other issues such as their substance or structure. ${ }^{21}$ However it is characterized, the fusion of a "hard," legally binding agreement with "soft," indeterminate language is a common, yet problematic, trade-off ${ }^{22}$ that merits separate analysis, particularly in the context of arms control regimes that attempt to regulate potentially destabilizing technology with both peaceful civilian uses and devastating military applications. ${ }^{23}$ This article thus focuses on indeterminate language in legally binding agreements, which represents one choice that states may make from a range of options for designing arms control and disarmament regimes.

One approach to resolving indeterminate legal terms involves delegating authority to judicial bodies to interpret ambiguous language. Since some degree of rule indererminacy is common in the domestic context, judges in domestic courts are often called upon to apply and interpret broad standards or to engage in the case-by-case administration of justice. ${ }^{24}$ Similarly, some international adjudicative bodies may also apply broad standards that require considerable interpretation and filling in of gaps. ${ }^{25}$ The resolution by third-party adjudication, however, of issues arising from indeterminate language in the arms control context generally represents an unacceptable threat to the sovereignty and national security of states, particularly the most powerful ones. State actors operating in an anarchic and unforgiving security environment pursue policies with respect to international cooperation on the basis of their own selfinterested motives or preferences, ${ }^{26}$ and so approach disarmament regimes and other restrictions in the "high politics" arena of war and peace with great suspicion. While states may conclude that their interests are advanced by joining security regimes, the terms of governing international agreements are invariably subject to scrutiny and compromise. In this regard, stares-especially the most powerful states, which are accustomed to setting the rules of most

19 See Kal Raustiala, Form and Substance in International Agreements, 99 AJIL 581, 582 (2005) (suggesting that legality, substance, and structure can be viewed as "distinct design elements" that should be treated holistically in evaluating the effectiveness of international agreements).

${ }^{20}$ Atsuko Kanehara, Some Considerations Regarding Methods of International Regulation in Global Issues: Sovereignty and 'Common Interests, 'in INTERNATIONAL COMPLIANCE, supra note 16, at 81, 83.

${ }^{21}$ Raustiala, supra note 19 , at 582, 589-90.

${ }^{22}$ Whatever term is used to describe the result, if a broad conceptual framework is applied to the architecture of international agreements, placing indeterminate provisions in a legally binding agreement may be characterized as one of several possible "systematic trade-offs" between form and substance that states make in designing their international commitments. Id. at 581 .

${ }^{23}$ The security dilemmas that states routinely face in arms control regimes are likely to be significantly more pronounced or acute when such complex dual-use technology is regulated. See infra note 91 and corresponding text.

${ }^{24}$ Louis Kaplow, Rules Versus Standards: An Economic Analysis, 42 DUKE L.J. 557 (1992); Cass R. Sunstein, Problems with Rules, 83 CAL. L. REV. 953 (1995); Robert Weisberg, The Calabresian Judicial Artist: Statutes and the New Legal Process, 35 STAN. L. REV. 213 (1983).

${ }^{25}$ The W TO Appellate Body, for example, applies and interprets some indeterminate language in the context of economic regulation. Joel P. Trachtman, The Domain of WTO Dispute Resolution, 40 HARV. INT'L L.J. 333, 337-38 (1999). Similarly, "friendship, commerce and navigation" treaties contain standards that are sometimes interpreted by the International Court of Justice. See Kenneth J. Vandevelde, $A$ Brief History of International Investment Agreements, 12 U.C. DAVIS J. INT'L L. \& POL'Y 157, 164-65 (2005).

${ }^{26}$ Underlying state motivations may be described as "preferences" as to goals or outcomes as opposed to strategies or ways to reach goals. Robert Powell, Anarchy in International Relations Theory: The Neorealist-Neoliberal Debate, 48 INT'L ORG. 330 (1994). 
international regimes according to their interests ${ }^{27}$-are generally unwilling and unlikely to entrust their most important security interests to other states or to adjudication by international institutions. ${ }^{28}$

In view of the high stakes associated with international security cooperation, it is useful to assess the design of arms control regimes in the context of preferences that may underlie selfinterested state behavior. This article undertakes such an assessment and uses the BWC to explore the choices states make along a continuum of options that include various dimensions of soft and hard law. In doing so, it illuminares the hazards of choosing indeterminate language to perform critical regime functions amid unstable security conditions.

Many scholars proclaim the virtues of soft law, including that dimension characterized by indeterminacy of language. In the area of arms control, some suggest that different types of soft law may at least be no less effective than hard law, especially when widely supported norms are involved, ${ }^{29}$ or that they may in fact offer distinct advantages over hard law. ${ }^{30}$ While indeterminate language may serve as a useful tool for states in certain negotiations and agreements, this article shows that it is fatal to the success of arms control in general, and multilateral disarmament agreements in particular. Even with all the transparency measures imaginable (including intrusive monitoring and verification mechanisms), indeterminacy of the language delineating permissible behavior will doom arms control to failure. Such indeterminacy nor only robs commitments of credibility-making it impossible to solve the security dilemmabut also is likely to exacerbate the security dilemma, breeding more of the mistrust that feeds it. By cloaking defection in plausible legality, many acts of noncompliance may be legitimized. Moreover, indeterminacy permits discriminatory application of key rules, favoring powerful states and deterring weaker states from joining the regime. This set of problems is illustrated below by consideration of the indeterminate language that has helped undermine the BWC and may have worsened the BW arms race.

Part II of this article briefly reviews the development of international legal prohibitions related to biological weapons and examines the origins and nature of the indererminate BWC legal framework. Using the BWC to illustrate the process whereby states make various substantive and structural trade-offs in designing international regimes, it analyzes the compromises that led to the adoption of this framework. Part II concludes by summarizing the regime's

\footnotetext{
${ }^{27}$ See Stephen D. Krasner, Structural Causes and Regime Consequences: Regimes as Intervening Variables, in INTERNATIONAL REGIMES 1 (Stephen D. Krasner ed., 1983); see also Stephen D. Krasner, Global Communications and National Power: Life on the Pareto Frontier, 43 WORLD POL. 336 (1991).

${ }^{28}$ Bilateral arms control treaties help illustrate how states generally prefer recourse to unilateral measures or bilateral dispute resolution procedures rather than entrusting third parties with the power to interpret terms that relate to national security in such agreements. See, e.g., Note, Legal Models of Arms Control: Past, Present, and Future, 100 HARV. L. REV. 1326 (1987) (noting that the ABM, SALT I, and SALT II treaties all established a Standing Consultative Commission (SCC) to interpret ambiguous phrases but that the USSR and the United States never invited other parties to participate in SCC proceedings); Angela M. Bradley, Opposing Interpretations of an International Treaty: The Anti-ballistic Missile Treaty Controversy, 2 CHI. J. INT'L L. 295, 296 (2001).

${ }^{29}$ See, e.g., Richard L. Williamson Jr., Is International Law Relevant to Arms Control? Hard Law, Soft Law, and Non-law in Multilateral Arms Control: Some Compliance Hypotheses, 4 CHI. J. INT'L L. 59, 63 n. 14 (2003) (further arguing that "[1]ittle in arms control seems to depend on whether one thinks of this category as a subset of soft law or just very mushy hard law").

${ }^{30}$ See Barry Kellman, Protection of Nuclear Materials, in COMMITMENT AND COMPLIANCE, supra note 18, at 486, 494-95 (arguing that soft law makes a better framework than hard law for the regulation of nuclear materials protection); Abram Chayes \& Dinah Shelton, Multilateral Arms Control: Commentary, in id. at 521, 526 ("Soft law can make an important contribution because it can more quickly respond to changing weapons technologies that create uncertainty about the risks of the future strategic situation and the mechanisms to minimize them.").
} 
problematic and indeterminate provisions and provides an overview of the unsuccessful performance of the BWC to date.

Parts III, IV, and V analyze the combined effects on arms control regimes of indeterminacy and lack of transparency in the context of three groups of states, as defined by their preferences: defensive defectors, offensive defectors, and compliant or conformist states. This examination demonstrates how psychological and rational mechanisms associated with indeterminate language can enlarge existing security dilemmas, undermine cooperation, and impede the universality of arms control regimes. The analysis of the negative effects of indeterminacy on arms control regimes in the context of these three preference groups is then applied to the particular case of the BWC regime. Taking into account the possibilities for improved performance suggested by the assessment of indeterminate arms control regimes in highly insecure environments, parts III, IV, and V evaluate, within the three respective preference groups, the role that determinate provisions could play together with transparency in addressing the observed deficiencies of the BWC regime. The United States recently abandoned its support for BWC reform efforts that were consistent with such an approach and instead placed itself as the main obstacle to these widely accepted reform measures, expressing unilateralist sentiments and broad national security concerns that also reflected the opposition of the U.S. pharmaceutical industry to such measures.

Part VI concludes by briefly contrasting the experience of the BWC with that of other multilateral disarmament regimes to illustrate how states are increasingly using determinacy to regulate complex dual-use technology problems (that is, technology that can be used either for building prohibited weapons or for legitimate, peaceful purposes) related to WMDs, and it further considers the complementary role that determinacy must play in successful BW nonproliferation efforts generally.

\section{THE ORIGINS OF THE INDETERMINATE AND INEFFECTIVE BWC REGIME}

\section{The First Prohibition Against the Use of Biological Weapons}

Although its use in warfare has been relatively rare, disease is said to have been employed as a weapon as early as the Middle Ages. ${ }^{31}$ Practical considerations, however, greatly limited the use of biological agents as weapons, particularly as they were difficult to produce, store, and deploy, and were as likely to harm friendly forces as the enemy. Nascent efforts by states to regulate the increasingly destructive new weapons near the end of the nineteenth century included agreements banning the use of certain poisons and asphyxiating gases but not biological weapons. ${ }^{32}$ In spite of early efforts to ban asphyxiating gases, chemical weapons (CW) were used extensively in World War I and caused hundreds of thousands of casualties. After

\footnotetext{
${ }^{31}$ There are various primitive examples of biological warfare. See ROBIN CLARKE, THE SILENT WEAPONS 14 (1968); GEORGE DEAUX, THE BLACK DEATH: 1347, at 1444 (1969); Jeffery K. Smart, History of Chemical and Biological Warfare: An American Perspective, in 16 TEXTBOOK OF MILITARY MEDICINE: MEDICAL ASPECTS OF CHEMICAL AND BIOLOGICAL WARFARE 9, 12 (Frederick R. Sidell et al. eds., 1997).

${ }^{32}$ Convention with Respect to the Laws and Customs of War on Land, July 29, 1899, 32 Stat. 1803, 1 Bevans 247 (prohibited, inter alia, the use of poison or poisoned arms); Declaration Concerning Asphyxiating Gases, July 29, 1899, TEXTS OF THE PEACE CONFERENCES AT THE HAGUE, 1899 AND 1907, at 81 (James Brown Scott ed., 1908), 1907 Gr. Brit. TS No. 32 (Cd. 3751) (banned "the use of projectiles the sole object of which is the diffusion of asphyxiating gases"); Convention Respecting the Laws and Customs of War on Land, Oct. 18, 1907, 36 Stat. 2277, 1 Bevans 631 (included a declaration outlawing the use of asphyxiating gases).
} 
the war, widely publicized accounts of the suffering and death associated with CW led to various attempts by states formally and effectively to outlaw the use of all chemical weapons.

At a multilateral arms control conference in 1925 addressing the nonuse of poisonous gases, a prohibition on "the use of bacteriological methods of warfare" was proposed for the first time. ${ }^{33}$ The work of this conference resulted in the conclusion of the Geneva Protocol for the Prohibition of Poisonous Gases and Bacteriological Methods of Warfare on June 17, 1925 (Geneva Protocol), which banned the use of both chemical and biological weapons. ${ }^{34}$ However, banning biological weapons, in contrast to chemical weapons, was a new legal concept in 1925. Since any practical threat presented by these weapons in 1925 was merely imagined, the authors of the Geneva Protocol in effect sought to ban a weapon of the future. ${ }^{35}$ In doing so, states demonstrated the power of biological weapons to cause considerable fear and insecurity on a largely abstract level.

As an international agreement, the Geneva Protocol was significantly limited in the scope of its application. The text banned the use, in war, ${ }^{36}$ of biological weapons only against other states parties (not states generally), ${ }^{37}$ and did not ban the possession or development of these weapons. Many states also made reservations declaring that the obligations under the Protocol would cease to be binding on them if enemy states failed to respect its prohibitions, effectively making it a prohibition on the "first use" of chemical and biological weapons. ${ }^{38}$ Thus, the Protocol's de facto recognition of a potential defensive or deterrent basis for these weapons-coupled with the absence of any prohibition on their development, acquisition, possession, manufacture, or transfer-resulted in a legal framework that allowed states to conduct BW research, develop new biological weapons, and ultimately engage in BW arms races.

${ }^{33}$ 1st and 2nd meetings of the General Committee of the Conference for the Supervision of the International Trade in Arms and Ammunition and in Implements of War, League of Nations Doc. A.13.1925.IX. Although the term "bacteriological" has a narrower scientific definition than "biological," in legal contexts the two terms have been used interchangeably in disarmament negotiations since before World War II. See A. BOSERUP, CBW AND THE LAW OF WAR 43 (Stockholm International Peace Research Institute [SIPRI], The Problem of Chemical and Biological Warfare Vol. 3, 1973). The broad, modern international legal definition of biological weapons encompasses several known categories of pathogens and toxins and also includes those that may come from as yet undiscovered sources, "regardless of any technical developments." See GA Res. 2603A (XXIV) (Dec. 16, 1969); see also infra note 39. The broad scope of this general prohibition has been repeatedly reaffirmed by states at BWC review conferences.

${ }^{34}$ Protocol for the Prohibition of the Use in War of Asphyxiating, Poisonous or Other Gases, and of Bacteriological Methods of Warfare, June 17, 1925, 26 UST 571, 94 LNTS 65.

${ }^{35}$ As a forward-looking ban, the prohibition on the use of biological weapons envisioned by the Geneva Protocol was comprehensive in spirit. See BOSERUP, supra note 33, at 40-41. The all-inclusive scope of the prohibition was reinforced by the term methods of warfare, potentially extending its coverage to a wide variety of means, processes, designs, delivery systems, and types of targets. Id. at 71 .

${ }^{36}$ By agreeing to prohibit the use of biological weapons only "in war," the parties to the Geneva Protocol left open the possibility of using biological weapons in noninternational armed conflicts, or in other contexts not amounting to "war." See id. at 28-33.

37 Although the prohibition against the use of asphyxiating, poisonous, or other gases was viewed by some as a reaffirmation of an existing norm, the prohibition against biological weapons was an innovation that had not yet attained that status, leaving the parties bound in this area only "as between themselves according to the terms of this declaration." Id. at 21-23.

${ }^{38}$ See, for example, the reservations of France, the Soviet Union, and the United Kingdom, Geneva Protocol Reservations, SIPRI, High Contracting Parties to the Geneva Protocol (2005), available at < http://www.sipri.org/ contents/cbwarfare/cbw_research_doc/cbw_historical/cbw_historical.html $>$. Although forty-two states originally made reservations to the Protocol, many would later withdraw them upon becoming a party to the BWC. 


\section{The BW Arms Race}

The fears generated by biological weapons and the security dilemmas that states have faced in arming against BW threats have historically been compounded by fundamental identification problems associated with the development of these weapons. Since disease occurs naturally, a troubling question of intention has often arisen when the scientific or military establishments in adversary states have been reported to be in possession of components or technology with BW applications. ${ }^{39}$ It was in fact the fear of nonexistent weapons, the potential impact of technological advances, and the misperception of threats that first inspired several states to begin to develop their own BW programs shortly after the legal ban on their use was formalized in $1925 .^{40}$ In a remarkable testament to the power of these concerns, "misperceptions of enemy interest" appear to have compelled several states to begin building biological weapons soon after the Geneva Protocol was signed. ${ }^{41}$

Events in World War II further demonstrated the power of BW misperceptions to magnify security dilemmas and motivate states to pursue BW programs. Although after the war the lack of any large-scale German BW program was established, both Britain and the United States had misperceived a serious German BW threat during the war and responded by developing their own BW programs. ${ }^{42}$ Both countries also concluded that the best defensive arsenal should include offensive biological weapons and in 1942 Britain conducted tests that for the first time proved the effectiveness of bombs with BW agents. ${ }^{43}$

American efforts at the close of World War II to limit access to captured scientists responsible for Japan's infamous BW experiments on humans increased Soviet suspicions of U.S. intentions regarding new BW capabilities and set the stage for the Cold War BW arms race. ${ }^{44}$ While the United States had not shown great interest in BW research programs in the 1930s, efforts to build a BW program expanded rapidly at the end of World War II and funding was dramatically increased. ${ }^{45}$ After adopting a policy in 1956 to be "prepared to use chemical and

\footnotetext{
39 The regulation of biological weapons has always been complicated by the requirement of intention, while no such requirement is stated for chemical weapons. See INGRID DETTER, THE LAW OF WAR 258 (2d ed. 2000). Thus, the UN General Assembly has defined prohibited biological agents of warfare as "living organisms, whatever their nature, or infective material derived from them - which are intended to cause disease or death in man, animals or plants." GA Res. 2603A (XXIV), supra note 33 (emphasis added).

${ }^{40}$ J. PERRY ROBINSON \& M. LEITENBERG, THE RISE OF CB WEAPONS 332 (SIPRI, The Problem of Chemical and Biological Warfare Vol. 1, 1971) (arguing that during the interwar years groups of individuals in the most powerful states decided that potential enemy countries were interested in biological warfare when in fact it appears that in most countries other than Japan biological weapons were "at most the part-time concern of very small groups of people").

41 Id. at $332-33$.

42 SHELDON H. HARRIS, FACTORIES OF DEATH: JAPANESE BIOLOGICAL WARFARE 1932-45 AND THE AMERICAN COVER-UP 161 (1995); see also Barton J. Bernstein, Churchill's Secret Biological Weapons, BULL. ATOM. SCI., Jan./Feb. 1987, at 46, 47-49.

${ }^{43}$ Early U.S. BW planners concluded that "the best defense is offense and the threat of offense." U.S. National Academies, War Bureau of Consultants, Final Report (1942), quoted in ED REGIS, THE BIOLOGY OF DOOM: THE HISTORY OF AMERICA'S SECRET GERM WARFARE PROJECT 177 (1999). Britain conducted tests in which 25-pound anthrax bombs were dropped among tethered sheep on Gruinard Island off the coast of Scotland. TOM MANGOLD \& JEFF GOLDBERG, PLAGUE WARS 30 (2001); Bernstein, supra note 42.

${ }^{44}$ DANIEl BarenblatT, A Plague upon HuMANITY: THE SECRET HiSTORY OF AXIS JAPAN's GERM WARFARE OPERATION 207-09 (2004); MANGOLD \& GOLDBERG, supra note 43, at 27-28, 44; REGIS, supra note 43 , at $107-11$.

${ }^{45}$ Bernstein, supra note 42, at 49; Henry L. Stimson Center, History of the U.S. Offensive Biological Warfare Program (1941-1973), available at <http://www.stimson.org/cbw/?sn=CB2001121275>.
} 
bacteriological weapons in general war, "46 the United States embarked on extensive programs to test the lethality, survivability, and dispersal characteristics of biological agents.

\section{Choosing Indeterminacy and No Transparency: The Creation of the BWC}

At the height of the massive BW arms race in the midst of the Cold War, President Richard M. Nixon took the dramatic and unexpected step on November 25, 1969, of unilaterally renouncing the possession and use by the United States of "lethal biological agents and weapons, and all other methods of biological warfare," and declaring that all biological research in the future would be confined to "defensive measures such as immunization and safety measures." ${ }^{77}$ Although the stated goal was to advance world peace, the questionable military utility of biological weapons significantly influenced the opinions of U.S. decision makers. In spite of newly developed practical applications, President Nixon and U.S. military leaders had serious reservations about the effectiveness of biological weapons and believed that nuclear forces provided both sufficient and superior strategic deterrence for the United States. ${ }^{48}$

As the United States proceeded to destroy its BW arsenal, the United Kingdom continued its attempt to achieve a worldwide treaty banning biological weapons. ${ }^{49}$ In 1969 the British and Americans were able to agree on the final wording of such a treaty, but the Soviet Union adamantly opposed the effort even after the British removed language requiring enforceable verification measures. ${ }^{50}$ In August 1970, the Soviets suddenly dropped their objections to the proposal, and within a year the Americans, the British, and the Soviets were able to report the draft BWC to the United Nations for its approval. ${ }^{51}$ The BWC was opened for signature on April 10,1972 , and the United States became a party on January 22, 1975.52

Cold War scenarios, often modeled in game theory as iterated, two-person Prisoners' Dilemmas, might suggest that the United States and its allies became a party to the BWC to achieve what they hoped would be a Pareto-optimal disarmament arrangement with the Soviet

\footnotetext{
${ }^{46}$ National Security Council, Reg. NSC 5062/1 (Mar. 15, 1956), quoted in REGIS, supra note 43, at 177. This new policy appeared to be broad enough to envision the first use of biological weapons.

47 Richard M. Nixon, Statement on Chemical and Biological Defense Policies and Programs, 1969 PUB. PAPERS 461,461 (Nov. 25, 1969). The renunciation was later extended to cover the use and production of all biological toxins as well. MANGOLD \& GOLDBERG, supra note 43, at 56 n.22 (citing White House Press Release (Feb. 14, 1970)).

${ }^{48}$ MANGOLD \& GOLDBERG, supra note 43, at 55, 61. U.S. military officials believed that biological weapons were not likely to be useful for either tactical applications or strategic deterrence. President Nixon is quoted as telling his staff, "We'll never use the damn germs, so what good is biological warfare as a deterrent? If somebody uses germs on us, we'll nuke 'em." William Safire, Essays; Iraq's Ton of Germs, N.Y. TIMES, Apr. 13, 1995, at $\mathrm{A} 25$.

${ }^{49}$ In August 1968, the United Kingdom proposed a convention banning biological weapons by submitting a working paper to the Eighteen-Nation Disarmament Committee. Susan Wright, Evolution of Biological Warfare Policy, 1945-1990, in PREVENTING A BiologiCal ARMS RACE 26, 38 (Susan Wright ed., 1990).

${ }^{50}$ MANGOLD \& GOLDBERG, supra note 43, at 57.

${ }^{51}$ On December 16, 1971, the General Assembly approved the treaty by a vote of 110-0. GA Res. 2826 (XXVI) (Dec. 16, 1971).

${ }^{52}$ Following the Senate's advice and consent, President Gerald Ford ratified the treaty for the United States and also took the long-overdue action of ratifying the Geneva Protocol, doing so with no reservations regarding the use of biological weapons.
} 
Union. ${ }^{53}$ Such paradigms do not, however, fully explain this Cold War transaction, particularly since its impact on third parties significantly informed U.S. preferences. ${ }^{54}$ As a balanceof-power issue, the spread of biological weapons was seen by American strategists as an undesirable way for relatively weak countries to obtain great destructive capability, while at the same time reducing the U.S. advantages in the acquisition and deployment of expensive conventional and nuclear forces. ${ }^{55}$ Believing that most states were not yet in a position to develop advanced biological weapons, the United States and Britain sought to negotiate the BWC with the Soviet Union quickly, in part to lock in existing strategic advantages over less developed states. $^{56}$

While the Soviets obtained their key objective by eliminating any mandatory transparency measures in the BWC regime, the United States and Britain obtained what they thought was a critical Soviet concession by signing a "hard" legally binding instrument. In hindsight, this was a dubious achievement for the Western powers since a legally binding agreement gave the Soviets a deceptive legal cover for a massive offensive BW program when an informal arrangement might not have falsely raised such expectations of their compliance. From the outset, Soviet acquiescence in a legally binding BWC appears to have been a cynical maneuver that enabled the clandestine building of the largest BW research and armament program in history. ${ }^{57}$ The Soviet Union was not, however, the only state to seek compromises that would ultimately weaken the BWC.

In negotiating the design of agreements, states may face a wide range of trade-offs in substance, structure, and obligation that include hard and soft levels of legalization, and thus yield different types of commitments and different degrees of difficulty in achieving these agreements. ${ }^{58}$ Various forms of soft law are touted by scholars as an easier way for states facing these choices to achieve desired objectives, to accommodate different interests through short-term compromises, and to provide the flexibility to address uncertainties and other issues. ${ }^{59}$ In the case of the final compromise BWC text, the design elements chosen by the drafting parties - hard legally binding obligations, soft structure (lacking any

\footnotetext{
${ }^{53}$ Although there are at least seventy-eight different two-person, two-strategy games, game theorists and political scientists have often focused on the Prisoners' Dilemma and its associated problems, even though it does not apply to most conflicts. WILLIAM POUNDSTONE, PRISONER's DilemMA 129 (1992). The Prisoners' Dilemma in fact became so commonly associated with nuclear arms rivalry that it was "oversold" as a paradigm for Cold War relations, sometimes overshadowing the realities of arms races. Id.

${ }^{54}$ Many arms races are not true Prisoners' Dilemmas since relativistic assessments of mutual armament and disarmament may appear to provide higher returns to one of the parties, resulting in a zero-sum game in which the equilibrium outcome is no longer Pareto-deficient. STEIN, supra note 10, at 126-27. While a disarmament agreement is more likely to meet the requirements for a true Prisoners' Dilemma, the parties negotiating such agreements may not be genuinely focused on reducing competition between themselves but may instead be more interested in achieving relative advantages over third parties. Id. at 133.

${ }^{55}$ See Letter from Matthew S. Meselson to Henry A. Kissinger, national security adviser (Sept. 1969), quoted in JUDith MilleR ET AL., GERMS: BIOLOGICAL WEAPONS AND AMERICA's SECRET WAR 62 (2001); Susan Wright, Introduction: In Search of a New Paradigm of Biological Disarmament, in BIOLOGICAL WARFARE AND DISaRMament: NeW PROBLEMS/NEW PerSPeCtIVES 3, 7 (Susan Wright ed., 2002).

${ }^{56}$ See Susan Wright, Geopolitical Origins, in BIOLOGICAL WARFARE AND DISARMAMENT, supra note 55, at 313,323 (drawing largely on declassified UK government biological arms control studies).

57 See Anthony Rimmington, The Soviet Union's Offensive Program: The Implications for Contemporary Arms Control, in BIOLOGICAL WARFARE AND DISARMAMENT, supra note 55, at 103, 121.

${ }^{58}$ See Abbott \& Snidal, supra note 17, at 436.

59 Id. at 423, 436 (noting how soft law can serve as a "compromise at a point in time" that can accommodate "different interests and values, different time horizons and discount rates, and different degrees of power"); Raustiala, supra note 19 , at 586,613 ; Weiss, supra note 16 , at 6 .
} 
access to transparency measures), and soft indeterminate language-reflected a complex set of preferences. Both the United States and Britain, like the Soviet Union, were clearly not eager to accept the sovereignty costs and security limitations associated with either precise requirements or intrusive inspections. ${ }^{60}$

Ambiguity in the BWC advanced important security objectives for the United States and Britain. The Western militaries in particular were unwilling to accept any clarifying distinctions between "peaceful" and prohibited BW activities, which resulted in the intentional placement by the Western powers of a fatal ambiguity at the heart of the BWC. ${ }^{61}$ While indeterminate provisions and a lack of transparency created a real possibility of future undetected defections, the ultimate national security interests of the Western powers were thought to be safeguarded in 1972 by powerful strategic nuclear deterrents. In the context of bipolar Cold War security and competition, the BWC drafting parties thus perceived a rational basis for eschewing both precision in their commitments and serious monitoring mechanisms, but this decision would have far-reaching consequences for the BWC regime when it was forced to confront BW proliferation challenges beyond the Cold War paradigm.

\section{Overview of the Indeterminate Provisions in the $B W C$}

The central obligation of the BWC is found in Article I, which requires each state party "never in any circumstances to develop, produce, stockpile or otherwise acquire or retain ... $[\mathrm{m}]$ icrobial or other biological agents, or toxins whatever their origin or method of production."62 This comprehensive ban, however, is limited in the same sentence to apply only to agents or toxins if they are "of types and in quantities that have no justification for prophylactic, protective or other peaceful purposes." ${ }^{63}$ The BWC offers no definitions of or clarifying rules on the types of biological agents that have "no justification for prophylactic, protective or other peaceful purposes." ${ }^{\prime 4}$ Similarly, both the obligation imposed upon states parties in Article II to destroy or convert to peaceful purposes all prohibited agents, toxins, weapons, or equipment in their possession and the prohibition in Article III preventing states parties from transferring prohibited agents, toxins, weapons, or equipment are explicitly made dependent on what might be included within the scope of the indeterminate phrase "peaceful purposes" found in Article I.

To provide for domestic enforcement of its treaty obligations, each BWC state party is required to take the necessary measures within its territory to prohibit and prevent the

${ }^{60}$ For a review of formerly classified internal documents detailing the British government's deliberations on joining the BWC and its assessment of the legal, political, and military implications of biological and chemical disarmament, see Wright, supra note 56, at 313-42. For a variety of reasons, including a desire to protect both commercial and military secrets, the Western powers were also reluctant to accept highly intrusive verification measures. Id. at 335 .

${ }^{61}$ Id. at 336; Jonathan B. Tucker, A Farewell to Germs: The U.S. Renunciation of Biological and Toxin Warfare, 1969-70, 27 INT'L SECURITY 107, 124 (2002) (discussing the desire of U.S. military planners to maintain a sufficient BW program to "avoid technological surprise by an enemy").

${ }^{62}$ BWC, supra note 1 , Art. I(1).

${ }^{63} \mathrm{Id}$.

${ }^{64}$ Weapons, equipment, or means of delivery of agents and toxins are also prohibited, provided that they are "designed to use such agents or toxins for hostile purposes or in armed conflict." Id., Art. I(2). 
development, production, stockpiling, acquisition, or retention of unlawful agents, toxins, weapons, and equipment. ${ }^{65}$ Once again, however, determining the extent of this prohibition depends on the vagaries of the term "peaceful purposes" as set forth in Article I. With respect to international enforcement, the BWC provides that a state party may submit a complaint of noncompliance to the UN Security Council, but the Convention does not specify any clear legal requirements or rules to invoke in lodging such a complaint, which must establish a "breach of obligations deriving from the provisions of the Convention."66

The lack of any determinate rules or criteria in the BWC also raises troubling issues with respect to the obligation of states parties to facilitate "the fullest possible exchange of equipment, materials and scientific and technological information for the use of bacteriological (biological) agents and toxins for peaceful purposes." ${ }^{267}$ With no definition of what constitutes "peaceful purposes," how can any state determine precisely what should be exchanged to the fullest possible extent, on the one hand, and what should be restricted, on the other, to prevent the proliferation of biological weapons? The lack of such a definition similarly complicates the obligation to implement the BWC so as to avoid hampering international cooperation and exchanges in "peaceful" biological activities. ${ }^{68}$

\section{Cheating Under the BWC, Insecurity, and the Failure of Reform Efforts}

Less than a year after it signed the BWC, the Soviet Union embarked on a massive clandestine cheating effort in which it concealed a vast network of BW research, development, testing, and production facilities within its existing civilian and military structures under the direction of an organization known as Biopreparat. ${ }^{69}$ Only after a major accident at a military microbiology factory in Sverdlovsk in 1979 and the subsequent defection of key scientists did the size and scope of the secret Soviet effort begin to become apparent. ${ }^{70}$

By the time the second BWC review conference of the states parties met in September $1986,{ }^{71}$ allegations of Soviet treaty violations, growing suspicions about the easily concealed

\footnotetext{
${ }^{65}$ The BWC envisions that states parties will do much of the policing, requiring each one to take "any necessary measures to prohibit and prevent the development, production, stockpiling, acquisition, or retention of the agents, toxins, weapons, equipment and means of delivery specified in article I of the Convention, within the territory of such State, under its jurisdiction or under its control anywhere." Id., Art IV.

${ }^{66} \mathrm{Id}$., Art. VI(1). Without $\mathrm{UN}$ action, resolution of disputes between states parties is subject only to voluntary consultation and cooperation under Article $V$.

${ }^{67}$ Id., Art. X(1). In addition, the states parties are encouraged to cooperate in contributing to the "further development and application of scientific discoveries in the field of bacteriology (biology) for prevention of disease, or for other peaceful purposes." Id.

${ }^{68}$ Id., Art. X(2).

${ }^{69}$ Rimmington, supra note 57, at 108-13; see also AMY E. SMITHSON, TOXIC ARCHIPELAGO: PREVENTING PROLIFERATION FROM THE FORMER SOVIET CHEMICAL AND BIOLOGICAL WEAPONS COMPLEXES 10 (HenrY L. Stimson Center Report No. 32, Dec. 1999), available at <http://www.stimson.org/cbw/pdf/toxicarch.pdf>; Jonathan B. Tucker et al., Biological Weapons Proliferation from Russia: How Great a Threat? in REPAIRING THE REGIME: PREVENTING THE SPREAD OF WEAPONS OF MASS DESTRUCTION 217, 217-19 (Joseph Cirincione ed., 2000).

${ }^{70}$ Michael Moodie, The Soviet Union, Russia, and the Biological and Toxin Weapons Convention, NONPROLIFERATION REV., Spring 2001, at 59, 60-61.

${ }^{71}$ States parties held a review conference five years after the BWC's entry into force to assure its provisions were being "realized." BWC, supra note 1, Art. XII. The first review conference was held in Geneva on March 3-21, 1980, and subsequent review conferences have since been held every five years.
} 
nature of recent advances in biotechnology, and the absence of effective BWC verification mechanisms led to the adoption of several voluntary confidence-building measures (CBMs) that called for the exchange of information about research centers and laboratories with highcontainment facilities and data on unusual outbreaks of disease. ${ }^{72}$ Amid continuing allegations of noncompliance, the third review conference in 1991 established a second set of CBMs, calling on states to provide information voluntarily on past offensive BW programs, vaccine production facilities, and relevant BW legislation, regulations, and other measures. ${ }^{73} \mathrm{The}^{\text {"Ad }}$ Hoc Group of Governmental Experts" (referred to as "VEREX") was also established to identify and examine potential verification measures from a scientific and technical standpoint. ${ }^{74}$ The need for such measures, as well as the shortcomings of the voluntary CBM process, was dramatically exposed a few months later, in early 1992, when Russian president Boris Yeltsin made a series of startling admissions about Soviet violations of the BWC. ${ }^{75}$

By 1994 it was generally acknowledged that voluntary CBMs were a failure, ${ }^{76}$ prompting a Special Conference of States Parties to establish the "Ad Hoc Group of States Parties" (Ad Hoc Group) to negotiate a more effective and legally binding verification regime for the BWC. ${ }^{77}$ The weakness of the existing BWC regime was made more apparent in the summer of 1995 when Iraq acknowledged that it had maintained an offensive BW program from 1975 until January 1991, even though it had previously claimed that it did not possess any biological weapons. ${ }^{78}$ Amid rising concerns about the BWC's ineffectiveness and Iraqi defiance of new UN inspections, the fourth review conference met in late 1996 and discussed the work of the Ad Hoc Group. After four and a half more years of negotiations, a "composite text" of a BWC draft protocol containing compromise language for outstanding bracketed issues was submitted by the chairman of the Ad Hoc Group and considered in April 2001. ${ }^{79}$

${ }^{72}$ Second Review Conference of the Parties to the BWC, Final Document: Part II, Final Declaration, Doc. BWC/CONF.II/13/II (1986), available at BWC Web site, supra note 7. These voluntary exchanges were conducted as a "consultation" activity under Article V.

${ }^{73}$ Third Review Conference of the Parties to the BWC, Final Document: Part II, Final Declaration, Annex, Doc. BWC/CONF.III/23 (Part II Annex) (1991), available at BWC Web site, supra note 7.

${ }^{74}$ Id., Final Declaration, Doc. BWC/CONF.III/23 (Part II), Art. V. In September 1993, VEREX issued a report concluding that a combination of twenty-one verification and assurance measures (including information monitoring, data exchange, remote sensing, inspections, and continuous monitoring) could help strengthen the BWC through increased transparency. See Ad Hoc Group of Governmental Experts to Identify and Examine Potential Verification Measures from a Scientific and Technical Standpoint: Summary Report, Doc. BWC/CONF.III/ VEREX/8, at 7-8 (1993), available at BWC Web site, supra note 7.

${ }^{75}$ Graham S. Pearson, The Essentials of Biological Threat Assessment, in BIOLOGICAL WARFARE 55, 75-78 (Raymond A. Zilinskas ed., 2000).

76 See Jonathan B. Tucker, The BWC New Process: A Preliminary Assessment, NONPROLIFERATION REV., Spring 2004, at 26,28, available at <http://cns.miis.edu/pubs/npr/vol 11/111/111 tucker.pdf $>$ (noting that since the first CBMs were developed in 1986, "only a small minority of member states have submitted the CBM declarations on a consistent basis").

77 For a review of the Ad Hoc Group's unsuccessful attempt to develop a BWC verification protocol and an examination of its different components, see JEZ LITTLEWOOD, THE BIOLOGICAL WEAPONS CONVENTION: A FAILED REVOLUTION (2005).

${ }^{78}$ Richard Butler, Inspecting Iraq, in REPAIRING THE REGIME, supra note 69, at 175, 175-78. Iraq signed the BWC on May 11, 1972, and finally ratified it on June 19,1991, after being directed to do so by the UN Security Council. SC Res. 687, paras. 8-10 (Apr. 3, 1991).

79 Protocol to the BWC, Doc. BWC/AD HOC GROUP/CRP.8 (draft, Apr. 3, 2001), available at BWC Web site, supra note 7 . The proposed legally binding text included provisions requiring states to make declarations regarding their biodefense programs and relevant facilities, to submit to routine site visits and challenge-type investigations of suspect facilities, and to permit investigations of suspicious outbreaks of infectious disease. 
On July 25, 2001, the U.S. ambassador to the twenty-fourth session of the Ad Hoc Group stunned delegates by unexpectedly rejecting the composite text of the draft protocol, arguing that it "would put national security and confidential business information at risk" and that it would "do little to deter those countries seeking to develop biological weapons." 80 Other than noting general national security risks and the proprietary concerns of the U.S. pharmaceutical industry, the United States offered no specific reasons for its actions, leading domestic and international observers to complain that the decision had been heavily influenced by the drug companies. ${ }^{81}$ The U.S. criticism of the draft protocol's ineffectiveness was all the more unexpected in view of the many changes that had previously been made in the text based on American objections. ${ }^{82}$ When the fifth review conference convened on November 19, 2001, the United States sought to terminate the Ad Hoc Group's discussion of legally binding multilateral measures altogether. Rejecting the draft protocol as a "flawed text" that would neither detect nor deter proliferators, the U.S. representative also named specific states that he said were not complying with the BWC obligations. ${ }^{83}$ With the draft protocol effectively dead, the fifth review conference was hastily adjourned and any further discussion of similar multilateral initiatives was suspended. ${ }^{84}$

Unsuccessful BWC reform efforts thus have been accompanied by allegations of extensive noncompliance, underscoring the regime's failings while exacerbating perceived threats that can contribute to further defections. In the absence of both effective transparency measures and determinate rules to define illicit activity, governments and nonproliferation experts remain in substantial disagreement over which states to accuse of misconduct or to include on lists of states possessing or pursuing BW programs. ${ }^{85}$ Although the U.S. government has obviously not included itself on any list of states of BW concern, many nonproliferation experts

${ }^{80}$ Ambassador Donald Mahley, Statement to the Ad Hoc Group of Biological Weapons Convention States Parties (July 25, 2001), at <http://www.state.gov/t/ac/rls/rm/2001/5497.htm>.

${ }^{81}$ See, e.g., Editorial, Germ-Warfare Abdication, BOSTON GLOBE, Nov. 16, 2002, at A18 (arguing that both the Clinton and Bush administrations "bought the dubious argument of representatives of the pharmaceutical industry that an aggressive system of international inspections might result in the disclosure of trade secrets"); Rachel Giese, Fear and Secrecy Along 49th Parallel, TORONTO STAR, Dec. 6, 2001, at A35.

${ }^{82}$ Michael Crowley, Letter to the Editor, Iraq's Weapons, INDEPENDENT (London), Dec. 5, 2001, at 2 (senior analyst, British American Security Information Council, noting that "the US consistently watered down suggestions for intrusive investigations due to concerns over national security and the protection of its pharmaceutical industry. It then rejected and effectively destroyed the whole protocol process on grounds that it would 'not improve our ability to verify compliance'.").

${ }^{83}$ John R. Bolton, Remarks to the 5th Biological Weapons Convention RevCon Meeting (Nov. 19, 2001), available at <http://www.state.gov/t/us/rm/janjuly/6231.htm>. The states that the United States accused of pursuing prohibited BW programs were Iran, Iraq, Libya, North Korea, Sudan, and Syria. The United States has continued to make such allegations against several of these countries, most recently at the sixth review conference in 2006 .

${ }^{84}$ See Fifth Review Conference of the States Parties to the BWC, Final Document, Doc. BWC/CONF.V/17 (2002), available at $\mathrm{BWC}$ Web site, supra note 7 . States parties have since been engaged in brief meetings designed to "discuss, and promote common understanding and effective action" on voluntary measures. Id., para. 18(a). Delegates to the sixth review conference in 2006 continued to avoid discussing any initiatives similar to the draft protocol and agreed on little beyond the need for continuing to talk. See Peter Crail, The Sixth Review Conference of the Biological Weapons Convention: Success or Failure? [interview of Jonathan B. Tucker] (Jan. 4, 2007), at $<$ http://cns.miis.edu/pubs/week/070104.htm > (observing that the fact that the conference was hailed as a success "suggests how dysfunctional the biological arms control process has become").

${ }^{85}$ With a lack of determinate rules and no monitoring mechanisms to confirm suspicions, there is predictable disagreement among experts about which states are states of BW concern. Various research institutes and nonproliferation experts list approximately a dozen states that, to varying degrees, could be considered of BW concern, with a higher level of consensus on the following nine countries: China, Egypt, India, Iran, Israel, North Korea, Russia, Syria, and, with growing reservations, Cuba. See JOSEPH CIRINCIONE ET AL., 
disagree and contend that the United States is itself contributing to an insecure BW environment by conducting research in expansive "biodefense" programs that appears to violate the BWC. ${ }^{86}$

\section{INDETERMINATE ARMS CONTROL REGIMES AND DEFENSIVE DEFECTORS}

\section{Indeterminacy in Multilateral Disarmament Regimes and Acute Security Dilemmas}

Security cooperation and state preferences. Given the dangers posed by surprise defections, states might be expected to pursue arms control activities with their rivals by establishing highly institutionalized hard law regimes that contain explicit definitions of cheating and specify elaborate verification and monitoring procedures. ${ }^{87}$ Contrary to these expectations, however, some scholars argue that states use a wide variety of forms of soft law in the area of arms control ${ }^{88}$ and that soft law may serve just as well as hard law for various types of arms control regimes or even offer distinct advantages. ${ }^{89}$ States may in fact be tempted to choose different dimensions of soft law as design elements for multilateral disarmament regimes for many of the same reasons they choose them in other areas of cooperation, perceiving these soft options as an easier way to promote maximum participation in such regimes while better addressing potential advances in technology or other uncertainties.

Although multilateral disarmament and bilateral arms control regimes share many common characteristics, the latter are usually associated with agreements between the United States and the Soviet Union that were based on nuclear parity, benefited from a variety of bilateral dynamics across many different fields of cooperation, and could rely on carefully scripted reciprocal behavior between the two parties that is hard to replicate in complicated multilateral relationships. Multilateral disarmament agreements present many similar security problems but must address more complex compliance issues and involve more complicated game theory models. ${ }^{90}$

DEADLY ARSENALS: TRACKING WEAPONS OF MASS DESTRUCTION 68 (2d ed. 2005); Arms Control Association, Chemical and Biological Weapons Proliferation at a Glance (2002), at <http://www.armscontrol. org/factsheets/>; Federation of American Scientists, States Possessing, Pursuing or Capable of Acquiring Weapons of Mass Destruction (2000), at<http://www.fas.org/irp/threat/wmd_state.htm>; Center for Nonproliferation Studies, Chemical and Biological Weapons: Possession and Programs Past and Present (2002), at <http://cns.miis.edu/research/cbw/>; Henry L. Stimson Center, Biological Weapons Proliferation Concerns (2007), at <http://www.stimson.org/cbw/?sn=CB2001121274>.

${ }^{86}$ See, e.g., Seth Brugger, Briefing Paper on the Status of Biological Weapons Nonproliferation (Arms Control Association, Sept. 2002, updated by Kerry Boyd, May 2003), available at < http://www.armscontrol.org/ pdf/bwissuebrief.pdf >; see also Milton Leitenberg et al., Biodefense Crossing the Line, 22 POL. \& LIFE SCI. 1, $1-2$ (2004).

${ }^{87}$ See STEIN, supra note 10, at 97, 40; Guido den Dekker, The Effectiveness of International Supervision in Arms Control, 9 J. CONFLICT \& SECURITY 315 (2004).

${ }^{88}$ See Chayes \& Shelton, supra note 30, at 523-24 (arguing that "some of the most elaborate 'soft' international law" is in the area of arms control).

89 See supra notes 29 and 30.

${ }^{90}$ Williamson, supra note 29 , at 64 (suggesting that " $[\mathrm{t}]$ he role of law in fostering compliance may be quite different in bilateral arms control than in multilateral arms control"). Game theory suggests that in contrast to twoplayer scenarios, multistate Prisoners' Dilemma may be more difficult for participants to overcome. Further complications are created by increased monitoring costs and the likelihood of increased "undetected or unredressed freeriding." JACK L. GOLDSMITH \& ERIC A. POSNER, THE LiMITS OF INTERNATIONAL LAW 36 (2006). 
In spite of the many proponents and purported advantages of soft law in other contexts, its indeterminate dimension appears to be a dangerous choice for a design element in multilateral disarmament regimes, particularly when member states face acute security dilemmas and effective transparency measures are not available. The classic security dilemma, in which efforts by states to improve their own security lead other states to feel threatened, is heightened when dual-use technology problems further obscure states' intentions and make it more difficult to distinguish between defensive and offensive postures, the more so if offensive capabilities may involve a devastating new military advantage. ${ }^{91}$ While transparency measures designed to detect and discourage cheating may assist a regime operating in such an environment, an even more unstable environment for cooperation may be created by combining this lack of transparency with reliance on indeterminate language. The impact of indeterminacy on egoist state actors in these circumstances varies in accordance with the preferences underlying the strategies of states participating in the regime.

A state's preferences for compliance with obligations under a security regime or for noncompliance-referred to as "defection" from cooperation in game theory parlance-are often difficult to discern and defy rigorous scientific analysis. On the one hand, states are likely to have some identifiable self-interested security objectives that inform their preferences and underlie related weapons strategies. On the other hand, rationality does not necessarily provide a clear and unambiguous guide to their behavior, since states may make different rational assessments of their interests and of other states" actions. ${ }^{92}$ It is this "conflict of rationalities" that has made the Prisoners' Dilemma such a popular game theory for modeling international relations problems when states are uncertain about the actions of other state actors and must choose between cooperation and defection, particularly in the context of security regimes. ${ }^{93}$

Since the preferences of individual egoist state actors are based on their own imperfect assessments of their interests and of other states' behavior, three broad groups of state actors that reflect the sometimes overlapping preferences underlying weapons strategies constitute a useful lens for evaluating the impact of indeterminacy and lack of transparency on multilateral disarmament regimes. These three groups, defensive defectors, offensive defectors, and compliant or conformist states, are further divided into several subgroups for purposes of analysis.

The problem of defensive defection. Arms control agreements are often modeled as Prisoners' Dilemmas in which fear of exploitation contributes to a dominant strategy of cheating by state actors. ${ }^{94}$ While the Prisoners' Dilemma is applied to many different types of international situations, certain characteristics of the security context make cooperation in the area of disarmament uniquely problematic and more likely to inspire defensive defections. The inherently relative nature of military power creates intensely competitive conditions in a high-stakes security environment with little room for error. ${ }^{95}$ Furthermore, state actors face difficulties in evaluating their own security and in accurately determining what other states are doing, especially

${ }^{91}$ See Robert Jervis, Cooperation Under the Security Dilemma, 30 WORLD POL. 167, 186-206 (1978).

92 STEIN, supra note 10, at 97 . Thus, rational arguments may be made by states both for cooperation and for defection in any parcicular situation. Id.

${ }^{93} \mathrm{Id}$. While mutual cooperation is a Pareto-superior outcome to mutual defection, a state may also rationally choose to pursue a dominant strategy of defection regardless of other states' actions or it may choose to defect on a defensive basis to ensure that it at least achieves its maximum possible outcome in the context of feared noncooperation. Id.

${ }^{94}$ Id. at 40.

95 See Robert Jervis, Security Regimes, in INTERNATIONAL REGIMES, supra note 27, at 173, 174. 
when offensive and defensive motives are hard to distinguish and often result in similar policies perceived as threatening to other states. ${ }^{96}$ This potential for misperceiving the motives of other states and taking actions that inadvertently threaten others can lead to a "spiral model" of international politics: the influence of both perceptual and structural factors on the interaction of security-seeking states makes that security difficult for any of the actors to attain. ${ }^{97}$ Facing such a security dilemma, a member of a multilateral disarmament regime may have to contend with strong incentives to stage a successful surprise defection yet must remain on guard against having its own national security interests seriously damaged by another state's possible defection. ${ }^{98}$

Commentators have suggested a variety of techniques and structures to assure the mutuality of states' commitment to regimes and thus help to overcome the Prisoners' Dilemma in different areas of international concern. ${ }^{99}$ In the field of arms control, scholars have suggested that fears giving rise to defensive defections may be decreased by a system of "assurance" measures in which states inform potential adversaries about capabilities and facilitate or engage in actions that demonstrate their continuing compliance with the regime's obligations. ${ }^{100}$ Any transparency measures designed to provide assurances, however, may be undermined by the substance of those obligations. By using language designed to preserve flexibility and produce a widely accepted multilateral disarmament convention, states may sacrifice determinacy and incur costs that relate to the problem of defensive defections. On a foundational level, indeterminate normative standards in international regimes may be said to entail significant legitimacy costs ${ }^{101}$ while obfuscating what is expected of states for them to satisfy the regime's requirements. ${ }^{102}$ These qualities enhance neither overall confidence in a regime nor the ability of its members to provide mutual assurances of compliance in highly unstable security conditions, even if supported by strong transparency measures.

In addition to the uncertainty of states about the expectations regarding their compliance with indeterminate provisions, a fundamental related problem is the type of commitment a state signals by proposing an agreement containing such language. Other states that are asked to rely on this type of commitment, particularly in a multilateral security context, are likely to prefer an agreement that does a better job of providing assurances of compliance and demonstrating costs that the proposing state would bear if the agreement were violated. "Credible

${ }^{96} \mathrm{Id}$.

97 See Robert Jervis, Realism, Neoliberalism, and Cooperation: Understanding the Debate, 24 INT'L SECURITY 42, 49 (1999).

${ }^{98}$ Chayes \& Shelton, supra note 30, at 521.

${ }^{99}$ See, e.g., Jeffrey L. Dunoff \& Joel P. Trachtman, The Law and Economics of Humanitarian Law Violations in Internal Confict, 93 AJIL 404 (1999) (suggesting that an agreement providing enhanced individual responsibility for human rights violations in internal conflicts could overcome Prisoners' Dilemmas and help suppress incentives for states to defect when it is accompanied by commitment techniques that provide some assurance that the agreement will be performed, such as universal jurisdiction or some kind of mandatory "extraterritorial" jurisdiction); Laurence R. Helfer, Exiting Treaties, 91 VA. L. REV. 1579, 1631-32 (2005) (suggesting that the Prisoners' Dilemma may be overcome in some multilateral agreements by better ensuring iteration or an increased "shadow of the future" by restricting exit opportunities).

${ }^{100}$ Abbott, supra note 9, at 4-5.

${ }^{101}$ As Thomas Franck notes, indeterminacy also has costs and these costs are usually "paid in the coin of legitimacy." THOMAS M. FRANCK, THE POWER OF LEGITIMACY AMONG NATIONS 53-54 (1990). Franck further suggests that " $[t]$ he degree of determinacy of a rule directly affects the degree of its perceived legitimacy," and that "the more determinate the standard, the more difficult it is to resist the pull of the rule to compliance and to justify noncompliance." Franck, supra note 12, at 716, 714.

${ }^{102}$ FRANCK, supra note 101 , at 54-55. 
commitments" are said to respond to this need and are often modeled in the Prisoners' Dilemma and other theoretic game models involving strategic interaction, and have other applications in contracting theory, business, and government. ${ }^{103}$ In interest-based theoretic models, international relations scholars use the term "credible commitment" to explain situations in which a state, after binding itself or otherwise constraining its ability to act, communicates this undertaking to another state to give that state an incentive to change its behavior. ${ }^{104}$

To convey a credible commitment, the commitment a state makes in an international agreement to help induce another state to behave as it otherwise might not have done must be perceived by that other state as both genuine and costly to retract. Some scholars consider a legally binding agreement with the highest degree of formality to be the most convincing way for a state to express a credible commitment, and they view treaties and their related ratification process as the best way for states to signal such intentions. ${ }^{105}$ But the psychological effects of indeterminate language impair its ability to communicate such commitments even if packaged in formal legal documents. As modeled in game theory and analyzed in bargaining dynamics, imprecision ultimately undermines the credibility of both threats and promises however they are expressed. ${ }^{106}$

Credible commitments and the overall prospects for successful cooperation by members of disarmament regimes are weakened when key indeterminate provisions make the requirements for compliance difficult to identify, further complicating existing security dilemmas. As shown in iterated versions of theoretic game models, successful cooperation cannot emerge if players are unable to recognize defection when it occurs. ${ }^{107}$ Recognition problems in theoretic game models often translate into rule changes related to improved transparency or revised payoff structures, but in this situation the same lack of clear definitions that obscures defection also makes such rule changes ineffective.

In addition to the limited ability of various forms of soft law to convey credible commitments, some of its purported advantages may also be illusory in the context of arms control and disarmament agreements. One of the professed benefits of soft law is its ability to adapt to change so that states can first commit themselves to various forms of discourse and procedure

${ }^{103}$ See Thomas C. SCHelling, The STRATEgy OF CONFLiCt 21-52 (1960); Oliver Williamson, The MECHANISMS OF GOVERNANCE 48-49 (1985).

${ }^{104}$ See, e.g., James D. Fearon, Signaling Foreign Policy Interests: Tying Hands Versus Sinking Costs, $41 \mathrm{~J}$. CONFLICT RESOL. 68 (1997); Slaughter et al., supra note 14, at 386 (noting how Institutionalists focus on credible commitments in international relations theory as one of several mechanisms that can reduce the opportunity for cheating).

${ }^{105}$ See Charles Lipson, Why Are Some International Agreements Informal? 45 INT'L ORG. 495, 508, 511 (1991) (noting that states use treaties to "signal their intentions with special intensity and gravity," to "underscore the durability and significance of the underlying promises," and as "a conventional way of raising the credibility of promises by staking national reputation on adherence"); see also Jack L. Goldsmith \& Eric A. Posner, International Agreements: A Rational Choice Approach, 44 VA. J. INT'L L. 113, 127 (2003).

${ }^{106}$ JON HOVI, GAMES, THREATS \& TREATIES 16 (1998); SCHELLING, supra note 103, at 21-52. In terms of psychological mechanisms, experiments have demonstrated that a clear message that seems to make sense will be accepted regardless of its source, while a message with less clear content is more likely to be accepted only if it comes from a respected source. ROBERT JERVIS, PERCEPTION AND MISPERCEPTION IN INTERNATIONAL POLITICS $123(1976)$.

107 See ROBERT AXELrod, THe Evolution of COOPERATION 140 (1984) (suggesting that recognizing defection is an important requirement in promoting cooperation and that the "scope of sustainable cooperation can be expanded by any improvements in the players' ability to recognize each other from the past, and to be confident about the prior actions that have actually been taken"). 
that may eventually lead to the acceptance of deeper, legally binding rules; ${ }^{108}$ but the time continuum required for this successful transition is not at all certain, nor are the consequences of delay in different areas of cooperation. In some cases, it is possible that the losses associated with the increased propensity of states to violate soft law may not overshadow the gains from clearer and more effectively monitored commitments. ${ }^{109}$ Over time and in different contexts, however, soft law may prove to be less beneficial. In the case of multilateral disarmament agreements that must regulate dual-use technology, soft design elements selected as short-term compromises will ultimately fail if they cannot address the fears and insecurity that generate strong incentives for defensive defections.

Although various forms of soft law are promoted as superior design elements for regimes as enabling states in the short term to bridge the gaps between technological uncertainties and solutions, in the long term indeterminate soft law may in fact make it harder for states to manage risks associated with advances in technology in complex, legally binding arms control and disarmament regimes. When the scope of technological challenges becomes more certain, the parties to such agreements may be more likely to benefit from determinate provisions that establish a mechanism for managing and sharing risks and can also more readily take advantage of new technological improvements in related monitoring and verification capabilities. ${ }^{110}$ Bilateral arms control regimes in particular have demonstrared the importance of determinacy in helping to adapt to new security and technology developments and thus preventing disputes that could lead to defections. ${ }^{11}$ Although dynamic changes under multilateral disarmament regimes generally present a more complicated situation, ${ }^{112}$ determinacy is a critical requirement for these regimes in successfully adapting to dynamic technological, political, and strategic changes and preventing these changes from inevitably enlarging perceptions of threat.

Defensive quasi-defectors. A variant of defensive defection may arise in multilateral disarmament regimes when key rules are so vague or leave so much to discretion that states, especially the most advanced industrial ones, may engage in activities that could appear to be unlawful but arguably are consistent with their own self-serving interpretations of those rules. With their advanced technology, these defensive "quasi-defectors" can exploit the soft limits of indeterminate restrictions through sophisticated auro-interpretation of a regime's scientific and technical requirements, pursuing advanced research projects with offensive applications under the guise of strictly defensive measures.

${ }^{108}$ See Abbott \& Snidal, supra note 17, at 446; Chayes \& Shelton, supra note 30, at 526.

109 See Raustiala, supra note 19 , at 611.

110 See, e.g., AXELROD, supra note 107, at 140 (noting that the technical difficulties in monitoring nuclear explosions and distinguishing them from earthquakes under applicable test ban treaties were eventually overcome by advances in technology); Mohamed ElBaradei [IAEA director general], Nuclear Technology in a Changing World: Have We Reached a Turning Point? (Nov. 3, 2005), at <http://www.iaea.org/Archive/DgStatements/ 2005.html > (noting the key role of advanced technology in IAEA efforts to prevent nuclear weapons proliferation, such as the use of advanced nuclear forensic techniques to help to "reconstruct the chronology and nature of past nuclear activity, and to verify the origin of the associated nuclear material").

${ }^{111}$ If the terms of a bilateral arms control agreement are sufficiently dererminate, states have shown themselves able to establish procedures to control related technology even if it is currently unknown. See, e.g., Treaty on the Limitation of Anti-ballistic Missile Systems, Agreed Interpretations, Common Understandings and Unilateral Statements, Statement D, May 26, 1972, U.S.-USSR, 23 UST 3435, 3456, 944 UNTS 13 (committing the parties to conduct additional negotiations with a view to establishing appropriate limitations for future antiballistic missile systems if based on technologies utilizing physical principles not present at the time the treaty enters into force).

${ }^{112}$ See Edwin M. Smith, Understanding Dynamic Obligations: Arms Control Agreements, 64 S. CAL. L. REV. 1549, 1604 (1991). 
While a preference for defensive quasi defection by great powers may be motivated in part by the same perceptions and fears that drive other states to pursue BW programs, it may also be inspired by the forces that have inexorably driven powerful industrial states to conclude that, as a matter of security policy, they must develop or acquire the most advanced science and technology with potential military applications. ${ }^{113}$ Fearing technological inferiority itself and confronted with an "asymmetric diffusion of military technology" that can give an innovator a significant (if only temporary) advantage, great powers have historically sought the latest that science can offer and the best military technology that their opponents might possess. ${ }^{114}$

In an earlier era when security under bilateral arms control agreements was firmly based on mutual assured nuclear destruction, states sometimes intentionally cultivated uncertainty about their new technological capabilities so as to suggest additional deterrent capabilities. In the modern, post-Cold War environment where states confront security dilemmas under a multilateral disarmament regime with only indeterminate obligations, actions that create uncertainties about technological advances are more likely to inspire defections than deterrence.

Some legal scholars argue that precision itself is advantageous in international agreements, primarily as it relates to review structures and as it is applied by institutions charged with subsequently developing corresponding standards. ${ }^{115}$ However, in hard legally binding multilateral disarmament regimes operating in highly unstable security environments, the effect and significance of soft indeterminate provisions appears to extend beyond dependence on review structures to affect the preferences and security policies of states by generally making obligations harder to understand, credible commitments harder to convey, and noncompliance harder to recognize and easier to justify. Furthermore, while imprecision may not alter the formal legal status of a legally binding agreement, it may make it possible for a state to use the legality of the agreement itself to help create false expectations in other parties, thus assisting a noncompliant state in more successfully cheating on its obligations.

Indeterminate language may also considerably affect the behavior of states under legally binding arms control and disarmament agreements by creating loopholes through incomplete regulation. Imprecise or otherwise indeterminate language may effectively leave some weapons systems or related technology unregulated, just as some arms control and disarmament regimes explicitly remove certain weapons systems or technology from their coverage. Since agreements do not eliminate underlying state preferences and rivalries, language that fails to regulate related and strategically attractive weapons systems has historically had the effect of channeling arms races into those unregulated areas rather than ending the arms races themselves. ${ }^{116}$

${ }^{113}$ As long as the possibility exists that conflict will be conducted by force, "competition in the arts and the instruments of force" will take place. KENNETH N. WALTZ, THEORY OF INTERNATIONAL POLITICS, ANARCHIC ORDERS AND BALANCES OF POWER 180 (1979) (further suggesting that this competition will produce a tendency toward sameness of competitors and that contending states will imitate the military innovations of the country of greatest capability and ingenuity); see also JOHN J. MEARSHEIMER, THE TRAGEDY OF GREAT POWER POLITICS 231-32 (2001).

${ }^{114}$ MEARSHEIMER, supra note 113, at 231.

${ }^{115}$ See, e.g., Raustiala, supra note 19 , at 583 n.10.

116 See STEIN, supra note 10, at 133. A frequently cited example is the experience of the Washington Naval Armaments Treaty of 1922 in which the major naval powers of the world agreed to limit the construction of a variety of different types of ships then in existence, resulting immediately in a major arms race in the classes of ships not covered by the agreement. Charles H. Fairbanks et al., Arms Control to Arms Reductions: The Historical Experience, 


\section{Defensive Defectors and the BWC}

Because the highly insecure environment in which offensive and defensive BW activities are difficult to distinguish and misperceptions about dual-use biotechnology can aggravate security dilemmas, states have historically had considerable incentives to develop their own BW programs for defensive or deterrent purposes. The BWC regime, lacking any mandatory transparency measures, also lacks structural mechanisms to provide assurances of compliance to address those incentives, which may lead to a downward spiral of defections. This shortcoming is magnified by key indeterminate terms that make it harder for states to give each other credible commitments of compliance.

Inasmuch as the combination of soft structure and substance has made it difficult to detect and define noncompliance, the existing BWC framework has proved to be a highly ineffective design approach to reducing incentives for defensive defection in spite of its "hard" or legally binding status. These difficulties, in turn, have created an unstable and corrosive atmosphere of allegations and denials that has further diminished confidence in the regime and made it even more difficult for regime members facing acute security dilemmas to provide each other with assurances or credible commitments of compliance. Controversial, vague, and uncorroborated allegations by the United States have been particularly destructive. ${ }^{117}$ In the context of a regime already diminished by admitted acts of cheating and the failure of its members to agree on any appropriate reforms, continuing allegations of noncompliance aggravate the fears and misperceptions that have historically generated BW arms races and risk a chain reaction of more defensive defections that would create even more acute security dilemmas. ${ }^{18}$ Confidence has been further eroded by the continuing perception that the indeterminate BWC framework is unequal to addressing dynamic technological changes. ${ }^{119}$

The full scope of the problem of defensive defection under the BWC is impossible to establish through rigorous scientific methods. Clearly, however, numerous facrors contribute to such defections, including various regional and historical rivalries. More states in the Middle East are widely considered to be of BW concern than in any other region of the world, making conflicts there the most important regional rivalries to involve states with potential BW capabilities. ${ }^{120}$ Most of the Middle Eastern states are BWC states parties. Those that are not parties display a tentative or defensive legal posture toward biological weapons, having signed but not

WASH. Q., Summer 1987, at 59 (noting that the Washington Naval Treaty ironically encouraged the extraordinarily rapid emergence of the aircraft carrier).

117 Unsubstantiated allegations by the U.S. representative at the fifth review conference in 2001 that six specific states were pursuing illegal BW programs were accompanied by vague assertions of other noncompliant states that were not publicly identified. See Bolton, supra note 83 . These U.S. allegations were widely criticized as selective and politically motivated. Richard Wolffe, US Names Iran as Chief State Sponsor of Terror, FIN. TIMES (London), May 22, 2002, at 1. U.S. nonproliferation experts would also later claim that BW and other WMD intelligence had been exaggerated to make a case for unilateral American action against countries such as Cuba and Iraq. Steven $R$. Weisman, In Stricter Study, U.S. Scales back Claim on Cuba Arms, N.Y. TIMES, Sept. 18, 2004, at A5; Sonni Efron, Harsh Critic of U.N. Named Ambassador, L.A. TIMES, Mar. 8, 2005, at A1.

118 See Richard Falk, Inhibiting the Reliance on Biological Weaponry: The Role and Relevance of International Law, in PREVENTING A BIOLOGICAL ARMS RACE, supra note 49, at 241, 244.

119 As early as 1986, the BWC Conference of States Parties officially noted "apprehensions" about developments in microbiology, genetic engineering, and biotechnology, but could not agree on any serious reforms to address them. See Final Declaration, supra note 72, Art. I.

${ }^{120}$ Egypt, Israel, and Syria are widely viewed by nonproliferation experts and many governments as having offensive BW research programs or some level of BW capability. See supra note 85. 
ratified the BWC, while being obligated to refrain from the first use of biological weapons under the Geneva Protocol. ${ }^{121}$

Although a detailed examination of Middle Eastern security policies is beyond the purview of this article, considerable evidence suggests that a variety of defensive and deterrent motivations may inform the preferences of states there with respect to biological weapons. These factors include the legacy of several conflicts that have involved the use of chemical weapons, another weapon of mass destruction. ${ }^{122}$ Even states that commentators frequently associate with purely aggressive, expansionist, or offensive motives and policies, such as $\operatorname{Iran}^{123}$ and Saddam Hussein's Iraq, ${ }^{124}$ may have decided to develop or maintain BW programs at least in part to advance various defensive or deterrent objectives. Rather than being perceived by states as an integral part of strategic or tactical offensive forces or as an effective means to threaten other states, BW capabilities, on closer examination, may be of interest to many states in the region largely on the basis of their perception of a dangerous environment. ${ }^{125}$ To whatever extent defensive or deterrent motives underlie preferences that lead states in the Middle East or any other region to violate their BWC obligations, the regime remains inadequate to deal with this problem, as key indeterminate language and a lack of transparency measures impede the provision of assurances to reduce incentives for defensive defection.

\section{Defensive Quasi Defectors and the BWC}

As described above, fear of technological developments that could give an innovator a significant advantage appears to have been a major factor contributing to the participation of advanced industrial states in even the earliest BW arms races. The United States further justifies its current development of advanced technology with BW applications by incorporating an

${ }^{121}$ All states in the region are parties to the BWC except Egypt, Israel, Syria, and the United Arab Emirates (UAE); however, Egypt, Israel, and Syria are parties to the Geneva Protocol. See SIPRI, supra note 36. Egypt and Syria have signed but not yet ratified the BWC. See BWC Web site, supra note 7. Although Israel is a nonsignatory, it attends BWC review sessions as an observer.

${ }^{122}$ One of these legacies in the Middle East appears to be that WMDs are most likely to be used against states and populations that do not possess them, creating the strategic perception that the best deterrent against such weapons is the ability to launch an in-kind response. Peter Sabin, Restraints on Chemical, Biological, and Nuclear Use: Some Lessons from History, in NON-CONVENTIONAL-WEAPONS PROLIFERATION IN THE MIDDLE EAST: TACKLING THE SPREAD OF NUCLEAR, CHEMICAL, AND BIOLOGICAL CAPABILITIES 13, 15 (Efraim Karsh et al. eds., 1993) [hereinafter NON-CONVENTIONAL-WEAPONS PROLIFERATION].

${ }^{123}$ The alleged involvement of Iran in BW and CW programs apparently began as defensive measures in response to the extensive and devastating use of chemical weapons against it during the Iran-Iraq war (1980-1988) and is widely suspected of continuing. See Central Intelligence Agency, Unclassified Report to Congress on the Acquisition of Technology Relating to Weapons of Mass Destruction and Advanced Conventional Munitions, 1 January Through 30 June 2001 (2001), available at <https://www.cia.gov/cia/reports/archive/reports_2001.html>. Iran's interests in biological weapons thus did not originate in a strategy to use them to threaten other states in the region.

${ }^{124}$ The considerable deterrent value that Iraq perceived with respect to its apparent chemical weapons capabilities was extensively (and ironically) documented by U.S. investigators interviewing former Iraqi officials and reviewing Iraqi government records after the U.S. invasion of Iraq. See Transmittal Message, in 1 COMPREHENSIVE REPORT OF THE SPECIAL ADVISOR TO THE DCI ON IRAQ'S WMD 1 (2004) [hereinafter CIA COMPREHENSIVE REPORT], available at < https://www.cia.gov/cia/reports/iraq_wmd_2004/>. Saddam's view that WMDs had helped to save his regime on multiple occasions helps explain why he "purposely gave an ambiguous impression about possession as a deterrent to Iran," although this approach would have unexpected consequences for his regime in its relations with both the United Nations and the United States. Id. at 9.

${ }^{125}$ See Susan Wright \& Richard Falk, Rethinking Biological Disarmament, in BIOLOGICAL WARFARE AND DISARMAMENT, supra note 55 , at 413,421 . 
expansive version of self-defense in aggressive counterproliferation policies. Without determinate criteria, the restrictive phrase "peaceful purposes" does nothing to moderate the incentives powerful states may have to pursue questionable and expansive biodefense programs in pursuit of technological superiority.

Revelations of formerly secret U.S. biodefense projects form an empirical framework for examining the potentially limitless expanse of quasi cheating under the BWC and the related negative effects of indeterminacy in the highly insecure BW environment. After a series of articles appeared in the New York Times in September $2001,{ }^{126}$ the U.S. government admitted that it had recently conducted two clandestine projects, and was planning a third, which were designed to simulate offensive BW activities as part of U.S. biodefense efforts. ${ }^{127}$ Project Bachus was managed by the Department of Defense and resulted in the construction of a fully functional BW production facility at a Nevada test site. ${ }^{128}$ Project Clear Vision was managed by the Central Intelligence Agency and focused on building and testing a biological bomb based on a Soviet design. ${ }^{129}$ Project Jefferson was managed by the Defense Intelligence Agency and resulted in plans to develop a modified, vaccine-resistant strain of anthrax modeled after a Russian version. ${ }^{130}$

The biodefense projects revealed in 2001, which were not declared by the United States under applicable confidence-building measures, were widely criticized as either a clear violation of BWC obligations or a dangerous precedent that blurred the distinction between permissible defensive and prohibited offensive activities. ${ }^{131}$ In the aftermath of the attacks of September 11, 2001, several projects managed by the Department of Homeland Security and undertaken at the newly established National Biodefense Analysis and Countermeasures Center apparently involved the production of "small amounts" of weaponized microbes (and perhaps genetically engineered pathogens as well) and were also criticized as skirting the edges of BWC obligations. ${ }^{132}$ U.S. government officials have defended all U.S. biodefense projects as being "in compliance" with existing treaties. ${ }^{133}$ Such claims, however, highlight both the lack of clear rules under the BWC regime and the likelihood that powerful states will continue to use their advanced

126 Judith Miller et al., U.S. Germ Warfare Research Pushes Treaty Limits, N.Y. Times, Sept. 4, 2001, at A1; Judith Miller, When Is a Bomb Not a Bomb? Germ Experts Confront U.S., N.Y. TIMES, Sept. 5, 2001, at AS [hereinafter Miller, Not a Bomb].

127 Victoria Clarke, assistant secretary of defense for public affairs, U.S. Department of Defense, Regular Briefing (Sept. 4, 2001), available in LEXIS, Federal News Service File.

${ }^{128}$ Judith Miller, Next to Old Rec Hall, a 'Germ-Making Plant,' N.Y. TIMES, Sept. 4, 2001, at A6. Project Bachus was designed to assess the difficulties in constructing a BW facility using only commercially available components and to find out whether it emitted "signatures" for identification purposes. See MILLER ET AL., supra note 55, at 297-99; Miller et al., supra note 126.

${ }^{129}$ MILLER ET AL., supra note 55, at 290-96; Miller et al., supra note 126.

${ }_{130}$ MILLER ET AL., supra note 55, at 308-12; Vernon Loeb, U.S. Seeks Duplicate of Russian Anthrax; Microbe to Be Used to Check Vaccine, WASH. POST, Sept. 5, 2001, at A16.

${ }^{131}$ See Miller, Not a Bomb, supra note 126 (quoting a former U.S. arms control official as saying that other countries would call it "a dangerous violation of the treaty," and that "it surely appears to be a violation of the treaty in terms of common interpretation"); see also Seth Brugger, International Reaction to Secret U.S. Bio-weapons Research Muted, 31 ARMS CONTROL TODAY, Oct. 2001, at 22, 22 (quoting a European official as saying that the projects made "gray areas grayer still" when attempting to distinguish offensive from defensive activities under the BWC); Oliver Meier, On the Wrong Side of the Line? BULL. ATOM. SCI., Nov./Dec. 2001, at 19, 21.

${ }^{132}$ Joby Warrick, The Secretive Fight Against Bioterror, WASH. POST, July 30, 2006, at Al (quoting one arms control expert as saying that "[i]f we saw others doing this kind of research, we would view it as an infringement of the bioweapons treaty").

${ }^{133}$ Loeb, supra note 130. 
industrial capabilities to engage in quasi cheating to address perceived security threats or preemptively seek technological superiority. Even if a multilateral monitoring regime were present, the failure of the BWC clearly to define what is prohibited and what is "peaceful" leaves uncertain the status of many sophisticated biodefense research programs, underscoring the importance of combining determinate provisions and transparency measures to correct the regime's deficiencies.

The quest for technological BW superiority by powerful states that in turn leads to a quest for technological dominance can, if unchecked, also manifest itself in a search for new pathogens that "express traits that would render existing defenses useless." ${ }^{134}$ Apparent U.S. efforts to develop "defenses" under the BWC not only against known pathogens but also against imagined or futuristic ones, as evidenced by work performed on a genetically modified form of vaccine-resistant anthrax, are a case in point. ${ }^{135}$ The lack of evidence that any terrorist organization has the resources to develop genetically engineered bioweapons ${ }^{136}$ has led some commentators to suggest that U.S. efforts to develop such weapons in "biodefense programs" stem from other than purely defensive preferences. In addition to creating or aggravating perceived security threats, novel pathogens that owe their existence to the failure of indeterminate language in the BWC may also undermine overall BW nonproliferation efforts by advancing societal acceptance of the idea that the generation of new biological weapons is a normal and appropriate activity. ${ }^{137}$

The problem of incomplete regulation manifests itself in the BWC through the indeterminate phrase "peaceful purposes." Like other limited disarmament agreements that have inspired arms races in key areas that were not regulated, the BWC contains loopholes spawned by indeterminate language that can encourage the most powerful states to use their advanced technology to develop new biological weapons purportedly within those unregulated areas. By dangerously blurring distinctions between offensive and defensive designs and creating new and greater perceived BW threats for other states, these quasi defections further exacerbate the security dilemmas under the BWC.

\section{Hard Solutions for the BWC: Applying Determinacy to Defensive Defectors}

As seen above, although some scholars suggest that a hard legally binding agreement with the highest degree of formality is the most convincing way for states to signal a credible commitment, ${ }^{138}$ the formality of the treaty process actually allowed the Soviets to misrepresent the importance and durability of their commitment, illustrating the dangers of relying on hard legally binding agreements with soft substance and structure. ${ }^{139}$ While arms control theory posits that hard structures may also offer solutions to the problem of defensive defections, history suggests that even if mandatory transparency measures had been present, they would have

${ }^{134}$ Susan Wright, Taking Biodefense Too Far, BULL. ATOM. SCI., Nov./Dec. 2004, at 58, 63.

${ }^{135} \mathrm{Id}$. at $63-64$.

${ }^{136}$ Leitenberg et al., supra note 86 , at 3 .

${ }^{137}$ Wright, supra note 134 , at 65.

${ }^{138}$ See Goldsmith \& Posner, supra note 105, at 124-25; see also Chayes \& Shelton, supra note 30, at 526-27 (arguing that some evidence in arms control cases suggests that legally binding norms create their own compliance pull and that "a norm in a treaty may induce more conforming state behavior than one that is purely non-binding").

${ }^{139}$ Lipson, supra note 105, at 511 (noting that while treaty commitments can be used to deceive unwary states and create false presumptions of compliance, "[i]nformal agreements are less susceptible to these dangers. They raise expectations less than treaties and so are less likely to dupe the naive."). 
been undermined by the indeterminate standards in the BWC that make noncompliance difficult to recognize. ${ }^{140}$

If legally binding agreements and hard structures are insufficient, states may use hard, determinate legal commitments themselves as instruments for providing assurances, particularly in arms control regimes where the potential for damaging defections is high. To the extent that the legally binding nature of commitments may be used as an "exante sorting device" that helps a state to identify itself as a party that is less likely to defect, determinate provisions in such a commitment will probably make that device more credible and effective. ${ }^{141}$ Closely related to the role they can play as signaling and sorting devices, determinate provisions may provide further assurances through their expected impact on states that are tempted to defect in highly insecure environments. In this sense, determinate rules that clearly convey normative content can improve confidence in a regime and reduce overall incentives for defection by encouraging "gratification deferral." 142 If states in highly unstable security situations fear that their adversaries will be tempted to take advantage of opportunities to defect from cooperation under a disarmament regime, parties are likely to choose to comply with the rules and forgo the gratification of defection only if they have a longer-term interest in seeing a potentially beneficial rule reinforced. ${ }^{143}$ States can be expected to defer the attainable short-term gains of defection only if the regime's rules are sufficiently determinate to allow those states to foresee future situations in which the rules will operate to their advantage and benefits will be derived from strengthening and complying with the rules in the present. ${ }^{144}$

Another potential advantage of determinacy in combating defensive defections in an unstable security environment is its greater ability in some cases to deal with dynamic changes. In 1972 the flexibility of imprecise language was perceived by the drafting states (particularly the United States and the United Kingdom) as a mechanism for dealing with a variety of risks and technological uncertainties. The potential character and scope of advances in biotechnology and generic engineering are now much better known, as is the nature of the once-imagined BW threat. In addition, these advances not only create potential incentives for states to pursue BW programs, but also offer the possibility of new restraints on their development through improved monitoring technology and verification methods. ${ }^{145}$

${ }^{140}$ This problem was demonstrated by the contentious efforts of the British, Americans, and Russians to inspect each others' BW facilities in the early 1990 s without the benefit of agreed BWC benchmarks. See infra notes $181-83$ and corresponding text.

${ }^{141}$ Lipson, supra note 105 , at 508 (noting that states desiring to signal a binding commitment use formal agreements to raise the political costs of noncompliance and that these costs "are highest when the agreement contains specific written promises"); see also Raustiala, supra note 19, at 582 (noting how trade-offs between ex ante credibility and ex post flexibility are central to functionalist analysis).

142 See Franck, supra note 12, at 721 (noting that rules that lend themselves to broad interpretations, even for humane or rational reasons, are "unlikely to inhibit any state from pursuing every opportunity for short-term interest gratification"); Claire R. Kelly, The Value Vacuum: Self-Enforcing Regimes and the Dilution of the Normative Feedback Loop, 22 MICH. J. INT'L L. 673, 706 (2001).

${ }^{143}$ Franck, supra note 12 , at 716.

${ }^{144} \mathrm{Id}$.

${ }^{145}$ Malcolm R. Dando, New Developments in Biotechnology and Their Impact on Biological Warfare, in ENHANCING THE BIOLOGICAL WEAPONS CONVENTION 21 (Oliver Thränert ed., 1996) (hereinafter ENHANCING THE BWC]. 
The experience of bilateral arms control agreements demonstrates that the parties must be able to address themselves to a number of "dynamic obligations" and must be prepared to monitor and adapt to changes in both the strategic and the technological contexts. ${ }^{146}$ Many of these agreements involve highly determinate attempts to regulate weapons systems, together with elaborate and intrusive inspection procedures that are structured to provide an adequate basis for responding to such changes and minimizing the associated risks. A bilateral arms control or multilateral disarmament regime that does not regulate clearly defined weapons, facilities, and related materials can neither effectively transmit information to its members about mutual compliance with obligations nor effectively communicate important political, technological, or strategic changes related to those weapons in member states. Such changes may be particularly relevant in the BW context.

The ability of hard law to provide a basis for positively responding to dynamic changes may be especially important in the Middle East where, as previously noted, there appear to be incentives for defensive defection from the BWC. Determinacy, together with legally binding transparency measures, might assist both in providing better assurances of compliance to states and reducing incentives for defection, and in promoting deeper cooperation by taking advantage of new political, technological, or strategic developments that relate to diminished or reevaluated interest in biological weapons in the region.

Several recent developments, including the confirmed elimination of all weapons of mass destruction in Iraq ${ }^{147}$ and the apparent abandonment of all WMD programs in Libya, may now provide an impetus for states in the Middle East to reappraise the utility of BW programs and the desirability of joining legal regimes to prohibit them. Many of the same factors that have historically limited the effectiveness of biological weapons elsewhere have an even larger presence in the Middle East, making BW unlikely weapons of choice there, thus potentially the subject of greater and more willing regulation by states. ${ }^{148}$ Some commentators have observed that BW programs may be less attractive to many states in the region than has been assumed. ${ }^{149}$ Moreover, as Egypt and Israel appear to be taking renewed, if only tentative, steps in the direction of increased cooperation regarding the $\mathrm{BWC},{ }^{150}$ determinacy and transparency

${ }^{146}$ Smith, supra note 112 , at 1582. As regards regulation of future technologies, see supra note 111.

${ }^{147}$ With its demonstrated ballistic missile technology, proclivity for CW use, and previously declared BW arsenal, Saddam Hussein's Iraq constituted a particularly difficult strategic predicament for states in the region, especially for Israel. Avner Cohen, Israel: Reconstructing the Black Box, in BIOLOGICAL WARFARE AND DISARMAMENT, supra note 55 , at $181,192-95$.

${ }^{148} \mathrm{Id}$. at 190 (noting that Israeli military strategists reportedly concluded that biological weapons could not be relied on for strategic deterrence or as an effective strategic or tactical military weapon, especially since most wars in the Middle East have been decisively terminated in a matter of days and leave no military use for "such uncertain weapons with a long incubation time"). The proximity of interdependent populations in a relatively small space has led others to argue that the use of WMDs such as biological weapons in the Middle East would be "highly irrational." Yezid Sayigh, Middle Eastern Stability and the Proliferation of Weapons of Mass Destruction, in NON-CONVENTIONAL-WEAPONS PROLIFERATION, supra note 122, at 179, 180.

${ }^{149}$ See Jonathan B. Tucker, Motivations for and Against Proliferation: The Case of the Middle East, in BIOLOGICAL WARFARE, supra note 75, at 27,33-35 (noting the uncertain military utility of biological weapons, the significant difficulties in delivering and preserving them in adverse meteorological conditions, and their very limited deterrent value compared to other WMDs and even conventional weapons). Experts note that Israel in particular, because of its nuclear weapons capability, now has little strategic reason to maintain BW capabilities or a posture of " $\mathrm{CBW}$ ambiguity." Cohen, supra note 147, at 202.

${ }^{150}$ Despite Egypt's status as only a BWC signatory state and Israel's status as a nonsignatory observer, both countries participated in the fifth and sixth review conferences and Egypt actively participated in the work of the Ad Hoc 
appear to be critical and timely tools for making the BWC framework better able to provide assurances, reduce incentives for defection, and positively reflect dynamic changes in the security environment. In the absence of such reforms, voluntary, self-reporting CBMs such as those now attached to the BWC do little to enhance cooperation and may instead be used or perceived as a source of disinformation that can worsen suspicions and give rise to more defensive defections. ${ }^{151}$

\section{Hard Solutions for the BWC: Applying Determinacy to Defensive Quasi Defectors}

While quasi defections are less likely to occur if transparency and determinacy are incorporated into the BWC regime, a powerful state may be deterred from adopting a hard law approach for any multilateral disarmament regime by various trade-offs that include forgoing perceived national security benefits derived from the continued exploitation of indeterminate language and structural deficiencies in transparency. At the same time, determinate rules and mandatory transparency provisions will probably not be adopted and succeed in the BWC without the support of the great powers, which is likely to be based on a calculated judgment that multilateral regulation is superior to individualistic behavior. ${ }^{152}$ Such a judgment may involve various factors but will doubtless depend on a self-interested evaluation by each state of its national security interests. To forgo individualistic security measures, states such as the United States must perceive such measures as more costly than the burdens imposed by determinate hard law, increased multilateral regulation, and the resulting sovereignty costs. Hard law often incurs sovereignty costs by fundamentally encroaching on a state's exclusive control over matters such as national security. ${ }^{153}$ Furthermore, even a limited delegation of authority, such as of certain responsibilities to an outside monitoring organization, may entail additional or unanticipated sovereignty costs. ${ }^{154}$ These costs will probably be important factors in evaluating the trade-offs inherent in choices along a continuum of options that include various dimensions of what can be described as hard and soft law. ${ }^{155}$

While a political Realist might suggest that the U.S. rejection of the BWC draft protocol resulted inevitably from the prevalence of national interests over those of a multilateral regime, powerful states may nonetheless join such a regime and embrace determinate, hard law commitments if they decide to seek long-term security benefits over maximizing short-term or myopic interests. ${ }^{156}$ The United States is one of many states that support the principles and objectives of the BWC; it begins its evaluation of the long-term benefits with strong incentives

Group. Three signatories in the region, Egypt, Syria, and the UAE, were also invited to participate in the preparatory work for the sixth review conference.

${ }^{151}$ See Laura Drake, The Middle East: Integrated Regional Approaches to Arms Control and Disarmament, in BIOLOGICAL WARFARE AND DISARMAMENT, supra note 55, at 151, 166-67.

152 Jervis, supra note 95 , at 176.

153 See Abbott \& Snidal, supra note 17, at 438 ("Even the most powerful states recognize that legalization will circumscribe their autonomy.").

${ }^{154}$ Id.

155 General, but unexplained, concerns about such costs were expressed by the United States in rejecting the final composite text of the BWC draft protocol in 2001. See John R. Bolton, The U.S. Position on the Biological Weapons Convention: Combating the BW Threat (Aug. 26, 2002), at <http://www.state.gov/t/us/rm/13090.htm > (saying that the draft protocol "would have compromised national security").

${ }^{156}$ Noting that Realists such as Hans J. Morgenthau have observed that "the national interest wins out over the international objective" in many areas, Robert Keohane suggests that such views ignore the possibility that states may nonetheless choose international cooperation by defining their interests more broadly and by eschewing immediate or "myopic" interests. ROBERT O. KEOHANE, AFTER HEGEMONY 99 (1994). 
to make the BWC regime more effective and to discourage $\mathrm{BW}$ proliferation, even at the expense of some immediate interests. ${ }^{157}$ Further, the United States originally led efforts to strengthen the BWC and has accepted hard law commitments and subjected itself to intrusive inspection and monitoring measures under other arms control and disarmament agreements like the Chemical Weapons Convention (CWC). ${ }^{158}$ Notwithstanding the advancement of many worthy goals, this apparent self-abnegation is likely to have been based on a rational and studied pursuit by the United States of its own security interests. Such efforts also involved a view of long-term interests that does not appear to have been dominated by any one American business interest, unlike the influence apparently exercised by the U.S. pharmaceutical industry with respect to BWC reform initiatives.

In contrast to the national security benefits that may flow from determinacy and transparency, powerful states may incur national security costs in choosing to continue the individualistic pursuit of expansive biodefense programs under the indeterminate provisions of the BWC. For example, biodefense programs may themselves present troubling limitations and risks relevant to calculating the costs of national security trade-offs. While these programs are strongly supported by the U.S. government, many BW experts argue that it is virtually impossible to protect an entire civilian population from a surprise biological attack and note that this problem contributed to the original decision by the United States to renounce its BW programs in $1969 .{ }^{159}$ Vaccination programs are problematic since they are unlikely to be able to develop and administer effective vaccines to protect a civilian population against a variety of specific unknown biological agents. ${ }^{160}$ On the other hand, vaccines are essential for personnel working on offensive $\mathrm{BW}$ programs and may be viewed as particularly suspect by other countries when they are developed by military organizations. ${ }^{161}$ Countermeasures against those vaccines can also lead to qualitative BW proliferation, as states attempt to circumvent the protection provided by other states' immunization programs. ${ }^{162}$ Even if states believe they are taking legitimate defensive actions, without agreed-upon determinate rules and transparency measures, extensive biodefense programs such as those pursued in new U.S. secret research centers may

157 Id. at 107.

${ }^{158}$ Convention on the Prohibition of the Development, Production, Stockpiling, and Use of Chemical Weapons and on Their Destruction, Jan. 13, 1993, S. TREATY DOC. NO. 103-21 (1993), 32 ILM 800 (1993) [hereinafter CWC].

159 See Laura Reed \& Seth Shulman, A Perilous Path to Security? Weighing U.S. "Biodefense" Against Qualitative Proliferation, in BIOLOGICAL WARFARE AND DISARMAMENT, supra note 55, at 57, 59. The unpredictable nature of the threat and the related inability of civil biodefense to prevent outbreaks from spreading out of control were important factors in the U.S. decision to renounce BW programs in 1969 and have continued to inform U.S. BW policy since that time. Id. at $59-60$.

${ }_{160} \mathrm{Id}$. at 72 (" $[\mathrm{I}] \mathrm{t}$ has been frequently pointed out that vaccines are useful only in the face of positive intelligence with respect to the nature of the hostile agent; similarly, treatment with drugs such as antibiotics is useful only for bacteria and only after the isolation and testing of the organism.").

161 See Victor W. Sidel, Defense Against Biological Weapons: Can Immunization and Secondary Prevention Succeed? in BIOLOGICAL WARFARE AND DISARMAMENT, supra note 55, at 77, 81 (noting that other nations may negatively view the intense interest shown by U.S. military researchers in vaccines intended to counter specific and rare organisms that are unlikely to cause public health problems unless intentionally spread); Richard Novick \& Seth Shulman, New Forms of Biological Warfare? in PREVENTING A BIOLOGICAL ARMS RACE, supra note 49, at 103, 112 (noting that since vaccines are more useful against agents contemplated for use as offensive weapons, their possession inevitably serves to "unbalance the international biological warfare situation"); see also Jonathan King \& Harlee Strauss, The Hazards of Defensive Biological Warfare Programs, in id. at 121 .

${ }^{162}$ Reed \& Shulman, supra note 159, at 68; see also Sidel, supra note 161, at 81 (noting that such circumvention appears to have motivated the Russians' search for a new strain of anthrax). 
easily raise suspicions in other countries that will exacerbate already dangerous security dilemmas. ${ }^{163}$ These concerns, together with fears about the safery and security of biodefense programs, have led some scientists to conclude that a more effective defense against these weapons may be improving the overall effectiveness of public health programs in the United States. ${ }^{164}$

A final national security trade-off that may be implicated by a powerful state's rejection of hard law to exploit the indeterminacy of the BWC is the inadvertent role of expansive biodefense programs in helping terrorist groups to acquire biological weapons. This threat appears to merit significant consideration in current U.S. national security calculations in light of the likely involvement of advanced, state-run biodefense labs in the 2001 anthrax letter attacks. Effective biological weapons capable of causing catastrophic casualties remain difficult to produce and deploy, and terrorist groups probably cannot launch such attacks on their own. ${ }^{165}$ Accidents at U.S. biodefense facilities may pose another threat to public health and national security, as evidenced by recent incidents involving the reappearance of relatively rare infectious diseases in America linked to state-run BW research facilities and state-funded BW research projects. ${ }^{166}$

\section{INDETERMINATE ARMS CONTROL REGIMES AND OFFENSIVE DEFECTORS}

\section{Indeterminate Rules, Cheaters, and Rogues}

One much-analyzed preference, modeled in game theory, that is displayed by some states is to defect offensively from regime cooperation, that is, to cheat secretly and thus secure an advantage over other states that remain bound by the obligations of that regime. Indeterminate provisions that leave the rules of cooperation uncertain and make it easier to evade obligations are tempting devices for states to use in pursuing strategies based on

${ }^{163}$ See Warrick, supra note 132 (noting that critics of the NBACC fear that "its work fuels suspicions that could lead other countries to pursue secret biological research"). Such suspicions are increased by the close ties of the National Biodefense Analysis and Countermeasures Center to the U.S. intelligence community and the assignment of special CIA advisers to the lab. Id. While national security officials may be quick to draw inferences about aggressive behavior from the military posture of adversary states, they are often not inclined to apply this reasoning to their own behavior, incorrectly assuming that other states are aware of their peaceful intentions and see no threat or menace in their actions. JERVIS, supra note 106 , at 68.

${ }^{164}$ Choffnes, supra note 4, at 29 (arguing that expanding U.S. biodefense activities risks training and equipping would-be bioterrorists).

${ }^{165}$ Id. (noting that " $[\mathrm{t}]$ errorists who want to mount a major attack with bioweapons would need substantial help from state sponsors to do so"); Malcolm Dando, The Bioterrorist Cookbook, BULL. ATOM. SCI., Nov./Dec. 2005, at 34, 36 (describing "barriers to entry" as potentially quite high for terrorists seeking to develop "weapons on a destructive scale comparable to those developed by states for military use"); DANA A. SHEA \& FRANK GOTTRON, SMALL-SCALE TERRORIST ATTACKS USING CHEMICAL AND BIOLOGICAL AGENTS: AN ASSESSMENT FRAMEWORK AND PRELIMINARY COMPARISONS, at CRS-11 (Congressional Research Service, 2004), available at <http://fpc.state.gov/documents/organization/33629.pdf > (noting that some experts suggest that "development of weaponized biological agents presents remarkably high hurdles, particularly in mass dissemination, which would require teams of scientists with state backing to overcome").

${ }^{166}$ For example, the disease glanders had not been reported in English-language medical literature since 1949 until a young microbiologist was hospitalized in Maryland in March 2004. This incident reportedly occurred in the context of "research on agents of biological warfare." Arjun Srinivasan et al., Glanders in a Military Research Microbiologist, 345 NEW ENG. J. MED. 256, 256 (2001) (further noting that labs face difficulties in recognizing potential agents of biological warfare and that this case may serve as a harbinger of the resurgence of nearly forgotten diseases). In another incident in 2004, three laboratory workers at Boston University were exposed to the bacterium that causes tularemia. The workers were reportedly working on a vaccine to protect against bioterrorist attacks. Scott Shane, Exposure at Germ Lab Reignites a Public Health Debate, N.Y. TIMES, Jan. 24, 2005, at A13. 
this preference. ${ }^{167}$ Structural mechanisms including assurance devices that might otherwise be relevant to this problem will probably not be of assistance once a state adopts defection as its dominant strategy since in effect such a state is no longer an interdependent actor that can be influenced by the correction of misperceptions through confidence-building measures or other mechanisms for dispensing useful information about compliance. ${ }^{168}$ The need to reduce the likelihood of successful offensive defections in these circumstances primarily implicates intrusive inspection, monitoring, and other "verification" measures rather than assurance devices, particularly when states fear that other states have achieved, or may achieve, significant technological advances related to the development of advanced weapons systems. ${ }^{169}$ When a preference for cheating is adopted, however, indeterminacy in key provisions can undermine these structural safeguards by making it more difficult to detect and identify violations.

A subgroup of offensive defectors could be characterized as states that maintain a preference not only for violating their obligations under a specific arms control or disarmament regime, but also for disregarding their legal obligations generally. States that engage in aggressive, defiant, and lawless behavior have been given numerous labels but are often described by U.S. government officials and many other commentators as "rogue states." 170 While the term "rogue state" has no international legal standing and has been defined and used in many different ways, ${ }^{171}$ it is used here to characterize a state as "a perennial violator" of international rules. ${ }^{172}$ Such states may have various reasons for violating international norms and rules, including overall dissatisfaction with the status quo, ${ }^{173}$ yet their motives are often described as "irrational." ${ }^{74}$ If rogue states are irrational actors, they are presumably even less likely than other defecting states to respond to assurances, threats, or any other information from or about their

${ }^{167}$ Franck, supra note 12 , at 714,718 .

168 See STEIN, supra note 10 , at 65.

${ }^{169}$ Abbott, supra note 9, at 16 (noting that concern for offensive defections will be especially pronounced when states fear technological advances by other states that are "capable of producing one-time gains large enough to offset the likely future costs or, in the extreme case, to end the game").

170 The Department of State abandoned the term "rogue state" in 2000 in favor of other terms such as "state of concern." See Robert S. Litwak, What's in a Name? The Changing Foreign Policy Lexicon, 54 J. INT'L AFF. 375, 377, 379 (2001). The term has since been resurrected by the Bush administration and used prominently in official policy statements. See NATIONAL SECURITY STRATEGY OF THE UNITED STATES 13 (Sept. 2002), available at < hrtp:// www.whitehouse.gov/nsc/nssall.heml> [hereinafter 2002 NATIONAL SECURITY STRATEGY] ("new deadly challenges have emerged from rogue states and terrorists").

171 The term "rogue state" has been so overused that some scholars have argued that it is often little more than "an ideological tag with no content." Anthony Clark Arend, International Law and Rogue States: The Failure of the Charter Framework, 36 NEW ENG. L. REV. 735, 735 (2002).

172 Id.; see also 2002 NATIONAL SECURITY STRATEGY, supra note 170, at 14.

${ }^{173}$ Although the terms "rogue state" and "revisionist state" are sometimes used interchangeably, a revisionist state is best defined as a rational one that nonetheless takes risks and violates international norms in an effort to change the status quo, as exemplified by imperial Japan and Nazi Germany and their use of force to achieve greater power and influence in the 1930s. See Richard Falk, Re-framing the Legal Agenda of World Order in the Course of a Turbulent Century, 9 TRANSNAT'L L. \& CONTEMP. PROBS. 451, 458 (1999). While rogue states are also likely to be dissatisfied with the status quo, they tend to be marginal actors that threaten regional stability without the capabilities of a Hitler or a Stalin to challenge the entire international system. See Litwak, supra note 170 , at 387.

${ }^{174}$ For example, North Korea is a rogue state that is often characterized by U.S. government officials and other commentators as irrational. See Denny Roy, North Korea and the 'Madman Theory,' 25 SECURITY DLALOGUE 307, $316 \mathrm{n} .15$ (1994) (noting that "the great majority of analysts implicitly or explicitly accept the premise of North Korean irrationality"); see also Victor D. Cha, Hawk Engagement and Preventive Defense on the Korean Peninsula, 
adversaries, including attempts at deterrence. ${ }^{175}$ This conduct is consistent with theoretic game models suggesting that threats of penalties for noncompliance are not likely to be effective against irrational actors. ${ }^{176}$ Similarly, U.S. national security policies emphasizing preemptive military action reflect the perceived irrationality of rogue states and their inability to be deterred. ${ }^{177}$ By definition rogue states are not inclined to cooperate with other states or to comply with the obligations of a legal regime, arguably making even the most strictly enforced, verifiable, and hard legal obligations irrelevant to their conduct.

The presumed inability of any diplomatic or legal initiatives to influence the behavior of rogue states remains dependent on the characterization of these states as irrational actors. If instead they are motivated by any rational preferences, such as a desire to obtain economic concessions or technical assistance in exchange for compliance, indeterminate provisions cannot yield the clear rules needed to establish workable arrangements with other regime members to facilitate such exchanges. Distinguishing between activities that must be abandoned and those that may be assisted will probably be impeded by indeterminate provisions, especially if alleged violators can claim an inalienable or guaranteed right to pursue various peaceful activities involving dual-use materials, such as chemical components, biological agents, and nuclear technology, under applicable multilateral disarmament regimes.

\section{Offensive Defectors and the BWC}

Confronting the unrelenting efforts of states to maximize their relative power to secure their survival, the designers of international security regimes have long struggled with the problem of offensive defectors. While assurance measures are most closely linked with efforts to address defensive defections through the exchange of useful information related to compliance, more intrusive methods such as on-site inspections are often described as "verification" measures and are commonly associated with efforts to improve compliance by detecting cheating by states engaged in offensive defection. ${ }^{178}$ In both practice and theory, however, these two systems are closely related and are often combined in arms control and disarmament agreements so as to promote transparency more effectively. ${ }^{179}$ In attempting to remedy the much-criticized structural deficiencies of the BWC in this respect and to address the problem of potential offensive

27 INT'L SECURTYY 40, 46 (2002) (noting that the irrationality of the North Korean regime is commonly argued to be a threat to peace on the Korean Peninsula).

${ }^{175}$ See Winston P. Nagan \& Craig Hammer, The New Bush National Security Doctrine and the Rule of Law, 22 BERKELEY J. INT'L L. 375 (2004); Elaine Sciolino \& Steven Lee Myers, U.S. Study Reopens Division over Nuclear Missile Threat, N.Y. TIMES, July 5, 2000, at Al (quoting senior U.S. officials as rejecting deterrence against countries like North Korea because their leaders were "capable of irrational self-destructive behavior").

${ }^{176}$ See SCHELLING, supra note 103 , at 130.

${ }_{177}$ In contrast to strategies for dealing with a status quo adversary in the Cold War, U.S. policy was revised in 2002 to reflect the view that "deterrence based only upon the threat of retaliation is less likely to work against leaders of rogue states more willing to take risks, gambling with the lives of their people, and the wealth of their nations." 2002 NATIONAL SECURITY STRATEGY, supra note 170 , at 15.

178 Abbott, supra note 9, at 4.

${ }^{179} I d$. at 5 . States will often have reasons to use both systems. Many bilateral arms control regimes are designed to mesh with various other external monitoring procedures and capabilities (such as satellites or other "national technical means"), the most extensive verification measures being dependent on the active cooperation of the parties under observation. Id. 
defections, the rejected BWC draft protocol envisioned a hybrid system of both assurance and verification measures. ${ }^{180}$

The current BWC framework appears to offer an inviting target for offensive defectors, as demonstrated by the ability of the Soviet Union and Iraq to develop illicit BW programs. While undetected cheating in such cases may often highlight the lack of transparency measures, the historical experience of the BWC also suggests that a lack of determinate rules and requirements will impede attempts to establish a meaningful verification process. Thus, in 1992 the United States, Britain, and Russia undertook to ascertain BWC compliance through a series of voluntary visits to nonmilitary sites of concern under the nonbinding "Trilateral Framework Agreement." 181 This process quickly ended in failure after several visits demonstrated Russia's unwillingness to give a full account of Soviet BW activities and accusations by both sides only intensified mutual suspicions. ${ }^{182}$ The absence of determinate rules or criteria contributed substantially to this failure, as participants could not agree on the implications of what they had observed during their visits. ${ }^{183}$

Even with transparency measures and determinate rules, the BWC regime would presumably not be able to affect offensive defectors characterized as "rogue" or outlaw states whose pursuit of BW programs is based on irrational motives. North Korea, for example, is often described as a particularly dangerous rogue and is also regarded by many governments and experts as a state of BW concern. ${ }^{184}$

In rejecting the BWC protocol, the U.S. government argued that a reformed BWC with access to some level of monitoring and clearer requirements would not deter determined cheaters and specifically accused North Korea of being such a cheater. ${ }^{185}$ While the United States also purportedly based this rejection on perceived flaws in the text and additionally cited the overarching concerns of the pharmaceutical industry, to the extent that it relied on the argument that such reforms cannot counter rogue states it remains dependent on the core assumption that these would-be cheaters are irrational and cannot be influenced by diplomatic efforts, or that arms control measures are useless in this area against any state, or both. The U.S. government continues to emphasize that no arms control or disarmament regime would deter any state that is determined to engage in illicit

\footnotetext{
${ }^{180}$ The BWC draft protocol incorporated many of the twenty-one identified verification and assurance measures recommended by VEREX. See supra note 74.

${ }^{181}$ David C. Kelley, The Trilateral Agreement: Lessons for Biological Weapons Verification, 2002 VERIFICATION Y.B. (Verification Research, Training and Information Centre) 93, 96-97.

${ }^{182}$ Id.; see also Moodie, supra note 70, at 66. U.S. officials found what they considered to be clear evidence of continuing offensive BW programs during their visits to several Russian facilities. Contentious Russian visits to Pfizer Corporation facilities in Indiana and Connecticut later resulted in accusations by Russian state media that Pfizer was producing biological weapons. See MILTON LEITENBERG, BIOLOGICAL WEAPONS ARMS CONTROL $11 \mathrm{n} .17$ (PRAC Paper No. 16, 1996), available at < http://www.cissm.umd.edu/papers/files/prac.pdf > . Although the trilateral process began in 1992, no further visits occurred after 1994 owing to disagreements over visits to military facilities.

${ }^{183}$ Moodie, supra note 70 , at 66.

${ }^{184}$ See Bolton, supra note 83 . For the findings of nonproliferation and research institutes regarding possible or alleged North Korean BW programs, see supra note 85 . North Korea was also designated by the United States as a dangerous member of an "axis of evil." George W. Bush, State of the Union Address (Jan. 29, 2002), 38 WEEKLY COMP. PRES. DOC. 133, 135 (Feb. 4, 2002), available at <http://www.gpoacces.gov/sou/index.html>.

${ }^{185}$ See supra note 85.
} 
biological weapons development, ${ }^{186}$ a view that conforms with a visceral dislike of international regimes that has sometimes been famously reflected in other comments by key U.S. officials. This attitude presents the question whether a stronger BWC regime would offer $a n y$ benefits in addressing the threat of determined offensive defectors and what costs or trade-offs, if any, would be incurred by adopting more determinate provisions and mandatory transparency measures.

\section{Hard Solutions for the BWC: Applying Determinacy to Offensive Defectors}

The possibility of mixed motives and their importance. Selecting design elements for an effective international regime is difficult when some members appear to have a preference for offensively defecting from cooperation to secure advantages over others. Even in such cases, however, the possible nuances in each state's preferences must be carefully evaluated if more effective legal regimes and sustained cooperation are to be achieved. ${ }^{187}$ Rather than reflecting a single motivation, the behavior of most states is more likely to be based on a constellation or combination of preferences. ${ }^{188}$

Russia is a country that may harbor a combination of preferences related to its BW programs. To the extent that it apparently continues to pursue offensive BW programs that it inherited from the Soviet Union, a preference for offensive defection remains a highly plausible motivation for some Russian actions. ${ }^{189}$ But Russia may also have some of the "great power" motives of a defensive quasi defector like those displayed by the United States, exploiting the indeterminate language of the BWC to be the first to acquire new, arguably permitted military technology and so avoid the unknown risks of any technological inferiority. ${ }^{190}$ In addition, Russia may be influenced somewhat by defensive or deterrent motives, and some writers even suggest that the Soviets were influenced by such factors. ${ }^{191}$ Finally, to some degree Russia may share some of the interests of many compliant states in ensuring the nonproliferation of biological weapons. $^{192}$

${ }^{186}$ Robert G. Joseph, under secretary of state for arms control and international security, Remarks to Carnegie International Nonproliferation Conference (Nov. 7, 2005), available at <http://www.state.gov/t/us/rm/ $56584 . \mathrm{hrm}>$ ("The traditional arms control verification approach .... would not have deterred those who would seek to violate the [Biological Weapons] Convention.").

${ }^{187}$ See Jervis, supra note 97, at 42, 53.

${ }^{188}$ STEIN, supra note 10 , at 48 . Even ancient Athens, whose aggressive conquests as recounted by Thucydides continue to be related by modern political Realists, was influenced by a combination of different motives. See Speech of the Athenians, in 1 SIMON HORNBLOWER, A COMMENTARY ON THUCYDIDES i.75.3, at 120 (1991) ("fear was our first motive, afterwards honour, and finally advantage").

${ }^{189}$ The Russian Ministry of Defense steadfastly continues to refuse to allow any access to four of its facilities (in Kirov, Sergiev Posad, Ekaterinburg, and St. Petersburg) that appeared to be at the center of the Soviet offensive BW program. See Rimmington, supra note 57, at 117.

${ }^{190}$ According to a prominent defector involved in the post-BWC Soviet BW program, many Soviet generals were not originally convinced of the military utility of biological weapons but felt that it was "dangerous, if not outrageous, to be behind the West in anything." See KEN ALIBEK WITH STEPHEN HANDELMAN, BIOHAZARD 41 (1999).

${ }^{191}$ There is some evidence even suggesting that the U.S. government may have deliberately atrempted to create a false impression of continuing work on BW programs to encourage the Soviets to dedicate resources on BW work rather than on other military programs. See Raymond L. Garthoff, Polyakov's Run, BULL. ATOM. SCI., Sept./Oct. 2000, at 40; Rimmington, supra note 57, at 109.

192 See Leonid A. Skotnikov, permanent representative of the Russian Federation to the Conference on Disarmament, Statement to the Fifth Review Conference of the States Parties to the BWC (Nov. 19, 2001), available 
The Russian BWC case illustrates the difficulties in discerning the specific preferences of states, especially when they may have incentives for secrecy and misrepresentation. To the extent, however, that states like Russia may be more than pure offensive defectors and may be motivated by a combination of preferences, determinacy and transparency in the BWC are likely to promote their cooperation with other similarly motivated parties. Strategies based on a more complicated set of preferences may account for Russia's continuing support of a legally binding multilateral monitoring agreement to strengthen the BWC and its insistence that such a document incorporate more precise or objective terms. ${ }^{193}$

The rogue or outlaw state. Although North Korea is often characterized as an irrational rogue or outlaw state and thus not influenced by factors that affect the behavior of other selfinterested states, a considerable amount of unpredictable, risky, or apparently irrational behavior by rogue states has been seen to be the product of miscalculations or misassessments. ${ }^{194}$ Using the term "rogue" to attribute irrationality to a potentially diverse group of aggressive or lawless states and then relying on that designation to establish policies may obscure an understanding of the individual motives or preferences that underlie the actions of each of these states. ${ }^{195}$

While the intensely secret and closed nature of the North Korean government defies efforts to explain its behavior or analyze its preferences fully, a sizable body of evidence suggests that rational decisions may nonetheless underlie many, if not all, of its strategies, ${ }^{196}$ all the more since its aggressive and threatening behavior has often served it well in its negotiations with more powerful countries. ${ }^{197} \mathrm{~A}$ rational state may find it quite useful to appear irrational, stubborn, or angry in a variety of circumstances. ${ }^{198} \mathrm{~A}$ combination of rational motives may therefore underlie many North Korean preferences, including those related to BW activities, which

at BWC Web site, supra note 7 (expressing concern about BW proliferation, calling for approval of legally binding multilateral verification measures for the BWC, and noting the enactment of criminal sanctions and export control laws to implement the BWC in Russia).

${ }^{193}$ Id. ("[W] would like to emphasize once more the importance that we have been and still are giving to the inclusion of terminology and objective criteria into the Protocol.").

${ }^{194}$ Predicting other states' capabilities and intentions involves inherent uncertainties and a "probabilistic assessment of an uncertain and unknown future," potentially leading to "bad predictions, miscalculations, and misassessments" by any state actor, including a rogue state. See STEIN, supra note 10, at 60-61.

${ }^{195}$ See Litwak, supra note 170, at 376, 379 (arguing that in the absence of a Cold War adversary, U.S. policymakers have used the term "rogue state" to demonize a disparate group of states in an effort to mobilize international and domestic political support for the adoption of "hard-line policies" against these states, potentially obscuring a better understanding of these states and distorting policy); see generally Zbigniew Brzezinski et al., Differentiated Containment, FOREIGN AFF., May/June 1997, at 20.

${ }^{196}$ Some critics question the assumption that the North Korean regime is irrational when it clearly seems interested in its own self-preservation and the United States has successfully contained it on the Korean Peninsula for many years. See Jihwan Hwang, Offensive Realism, Weaker States, and Windows of Opportunity: The Soviet Union and North Korea in Comparative Perspective, WORLD AFF., June 22, 2005, at 39; David C. Kang, Rethinking North Korea, 35 ASIAN SURVEY 253 (1995); Steven Mufson, Threat of 'Rogue'States: Is It Reality or Rhetoric? WASH. POST, May 29, 2000, at Al.

${ }^{197}$ Although North Korea is criticized for taking irrational risks, some commentators argue that it is a classic example of the effective use of threats, bluffs, blackmail, and brinksmanship to create crises in order to extract maximum concessions from more powerful countries. SCOTT SNYDER, NEGOTIATING ON THE EDGE (1999); Roy, supra note 174.

${ }^{198}$ Jack L. Goldsmith \& Eric A. Posner, A Theory of Customary International Law, 66 U. CHI. L. REV. 1113, 1135 (1999) ("Weak states with idiosyncratic domestic arrangements-like Iraq, Serbia, or North Korea-may benefit from being unpredictable or irrational."); Benedict Kingsbury, The Concept of Compliance as a Function of Competing Conceptions of International Law, in INTERNATIONAL COMPLIANCE, supra note 16, at 49, 55. 
presents possibilities for self-interested North Korean participation in a reformed BWC regime. Recent initiatives by the United States to engage Iran and North Korea by offering various incentives for better behavior, while hardly enthusiastic, suggest fundamental reconsideration by U.S. officials of the presumption of the irrationality of rogue states. ${ }^{199}$

One potentially important self-interested motive behind some alleged WMD activities of North Korea may be the desire to obtain maximum advantages or compensation from the international community in exchange for its participation in disarmament regimes, ${ }^{200}$ an approach facilitated by regimes that guarantee states the right to pursue "peaceful" research, development, exchange, and other activities closely related to prohibited undertakings. The BWC offers such guarantees, ${ }^{201}$ as do other agreements like the Treaty on the Non-proliferation of Nuclear Weapons (NPT). ${ }^{202}$ Under this type of regime, a state might demand concessions for an agreement to forgo otherwise permitted "peaceful" activities, arguing that full enjoyment of such activities would represent a trade-off or a form of "compensation" for the state's original willingness to subject itself to the terms of a disarmament agreement. ${ }^{203}$

Given the unproven military utility of biological weapons and the inherent limitations of a BW arsenal serving as an effective strategic deterrent, particularly when compared with nuclear weapons, ${ }^{204}$ North Korea could rationally conclude that BW programs are not essential for national security purposes yet at the same time decide that demonstrating full compliance with BWC obligations could be profitable. The incentives for a rogue state to behave in this way are potentially greater than for it to engage in any type of genuine security cooperation,

199 See Peter Baker \& Anthony Faiola, U.S., S. Korea Find Unity Against North's Nuclear Arms Program, WaSH. POST, Nov. 17, 2005, at A20 (noting how two years of six-party negotiations resulted in an offer of "economic incentives" in exchange for abandonment by North Korea of its nuclear weapons program). On February 13, 2007, North Korea is reported to have agreed to take certain incremental steps with respect to its nuclear programs, including shutting down the Yongbyang reactor and readmitting international nuclear inspectors, in exchange for energy aid and other inducements. Glenn Kessler \& Edward Cody, U.S. Flexibility Credited in Nuclear Deal with N. Korea, WASH. POST, Feb. 14, 2007, at A11. In the aftermath of an apparent North Korean nuclear weapons test, the UN Security Council appears to continue to display a belief in the ability of North Korea to make rational assessments by imposing a variety of sanctions designed to change its behavior. See SC Res. 1718 (Oct. 14, 2006). With respect to the Council's attempts to influence the behavior of the Islamic Republic of Iran and that country's continuing pursuit of economic and other concessions in exchange for actions related to its nuclear activities, see infra notes 273-76 and corresponding text.

${ }^{200}$ Efforts by North Korea to obtain various economic and other concessions have been a major part of its often aggressive negotiating positions with the international community with respect to its nuclear activities. See Nancy E. Soderberg, Op-Ed, Escaping North Korea's Nuclear Trap, N.Y. TIMES, Feb. 12, 2003, at A37 ("The history of negotiation with North Korea is one in which the international community has repeatedly offered incentives to North Korea to rein in its nuclear programs."). North Korea's vice foreign minister stated the issue bluntly: "Our demand is also for the U.S. to make due compensation for the freeze and dismantlement of nuclear facilities that we have built with huge investment, tightening our belts." Colum Lynch, North Korea Resists Talks on Nuclear Arms; Meeting by U.S. Election Is Unlikely, WASH. POST, Sept. 28, 2004, at A21.

201 See supra notes 67-68 and corresponding text.

${ }^{202}$ Treaty on the Non-proliferation of Nuclear Weapons, Arts. IV(2), X(2), July 1, 1968, 21 UST 483, 729 UNTS 161 [hereinafter NPT]; see infra notes 262-63 and corresponding text.

${ }^{203}$ David A. Koplow \& Philip G. Schrag, Carrying a Big Carrot: Linking Multilateral Disarmament and Development Assistance, 91 COLUM. L. REV. 993, 1034-35 (1991). For example, non-nuclear states such as Iran may argue that part of their "compensation" under the NPT for agreeing not to exercise their right to develop nuclear weapons is an inalienable right to acquire all forms of "peaceful" nuclear technology. See Henry Sokolski, Taking Proliferation Seriously, POL'Y REV., Oct. 1, 2003, at 18.

${ }^{204}$ See Tucker, supra note 149, at 33-34 (noting that it is highly unlikely that biological weapons could ever provide the same level of deterrence as nuclear weapons since nuclear retaliation is immediate, devastating, and effective against military equipment as well as troops, while biological weapons are "slow, uncertain in their effects, and incapable of destroying military hardware and buildings"). 
which comports with the view of scholars who argue that states like North Korea are probably more motivated to join a regime by profit than by security interests. ${ }^{205}$ While a self-interested North Korean regime might possibly be encouraged to participate in a reformed BWC regime, history has demonstrated that such a regime would require legally binding, precise hard law terms with access to verification measures as insurance that the international community will "receive" from North Korea what it "pays" for. ${ }^{206}$

The advantages of determinacy in enhanced enforcement. Even a strong international regime supported by a spectrum of self-interested member state preferences may at some point benefit from the availability of sanctions for noncompliance, especially if incentives for offensive defection grow as cooperation deepens. ${ }^{207}$ In this regard, determinacy may contribute to improving the BWC's limited enforcement mechanisms. Although reputational sanctions are clearly more effective when a regime imposes determinate, hard law obligations and has access to monitoring mechanisms so that violations are known to other state actors, ${ }^{208}$ reputational costs are less likely to affect states that are already viewed as cheaters or rogues. ${ }^{209}$ If, however, rational states are making a choice either to honor or to violate their international commitments, the availability of other, more effective sanctions could improve compliance by making the possible costs of a breach outweigh the costs of compliance, thus altering a state's payoffs. ${ }^{210}$

Few sanctions or enforcement options are available under the existing BWC framework. Beyond notoriously ineffective voluntary consultation procedures and domestic criminal penalties, ${ }^{211}$ the Convention contemplates the possibility of sanctions by enabling states parties to lodge a complaint with the Security Council in case of a breach of obligations under the Convention by another state party. ${ }^{212}$ Without determinate provisions to identify violations when

${ }^{205}$ Randall L. Schweller, Unanswered Threats, A Neoclassical Realist Theory of Underbalancing International Security, 29 INT'L SECURITY 159, 165 (2004); see also Randall L. Schweller, Bandwagoning for Profit: Bringing the Revisionist State Back In, 19 INT'L SECURITY 72, 87-89 (1994).

${ }^{206}$ The nonbinding "Agreed Framework," under which North Korea promised in 1994 that it would verifiably freeze certain nuclear-processing activities in exchange for Western assistance, collapsed in 2002 after North Korea refused to deny claims that it was secretly enriching weapons-grade uranium. Key ambiguous terms, especially those related to the timing and sequence of activities and assistance, had been disputed by both sides for many years and undermined effective cooperation. See Korean Reactions, FIN. TIMES, Aug. 9, 2002, at 14 ("[T] he Agreed Framework clearly contains many flaws and ambiguities that have stalled its implementation."). Beyond initial energy aid, receipt by North Korea of additional assistance under the agreement reached on February 13, 2007, appears to depend on meeting more determinate requirements than those found in the 1994 Agreed Framework. See Faces Saved All Around-The North Korean Nuclear Deal, ECONOMIST, Feb. 17, 2007, at 28, 30 (quoting the chief American negotiator as having repeatedly told the North Koreans "that America needed to know 'precisely' what was happening with uranium enrichment").

${ }_{207}$ George Downs et al., Is the Good News About Compliance Good News About Cooperation? 50 INT'L ORG. 379 , 397 (1996) (noting that " $[\mathrm{c}$ ]ooperation in arms, trade, and environmental regulation may begin with agreements that require little enforcement, but continued progress seems likely to depend on coping with an environment where defection presents significant benefits").

${ }^{208}$ See Guzman, supra note 14, at 1860.

${ }^{209}$ Reputational models have been criticized as overused or incomplete and the reputational costs associated with violation of international law in particular have been described as exaggerated or too heavily relied upon by scholars. See GOLDSMITH \& POSNER, supra note 90, at 102.

${ }^{210}$ Guzman, supra note 14 , at 1860 .

${ }^{211}$ The BWC relies on each state party to enact implementing legislation with appropriate criminal penalties under Article IV and to participate on a voluntary basis in additional consultation and confidence-building measures; most states have declined to participate in these voluntary measures. See supra note 76.

212 BWC, supra note 1, Art. VI(1). No state has ever availed itself of this right. 
they occur and without the benefit of any agreed multilateral monitoring mechanisms to confirm noncompliance, a state is unlikely to be able to submit a complaint that includes "all possible evidence confirming its validity." 213 Although the BWC requires no action on such complaints other than carrying out an investigation and informing states of the results, ${ }^{214}$ the Security Council has identified the proliferation of biological weapons and other WMDs as a "threat to international peace and security" 215 and would thus be able to impose a variety of enforcement measures on that basis if violations could be determined-and if no permanent member vetoed those measures.

To the extent that legally binding agreements with more precise obligations are credited by some scholars with an increased capacity for enforcement by bodies that are delegated that responsibility, ${ }^{216}$ determinacy in the BWC could make the possibility of Security Council action a more effective sanction, particularly if combined with transparency measures. The quasi-judicial or legalistically formal language in the BWC requiring the demonstration of a "breach of obligations" reinforces the need for determinate provisions that allow both allegations and potential defenses to be tested by agreed legal rules or requirements. ${ }^{217}$ As currently constituted, however, the indeterminate BWC framework makes the threat of sanctions almost nonexistent, projecting little deterrence to offensive defectors; this threat is further diminished by the BWC's lack of mandatory transparency measures.

Determinacy and drawing lines. Some legal scholars have suggested that international law itself is intrinsically indeterminate, essentially constituting a rhetorical fabric used by powerful actors to engage in international politics as they see fit. ${ }^{218}$ Although some degree of indeterminacy appears to be inevitable in any set of rules and too much precision may even undermine a rule's effectiveness, some outer boundary of a rule's elasticity must be established for it successfully to convey a message regarding required or prohibited conduct, ${ }^{219}$ especially as regards arms control. A certain degree of indeterminacy is inherent in any arms control or disarmament regime, but a high degree of indeterminacy is likely to undermine the regime's objectives, particularly if it is impossible to draw any bright lines between prohibited and permitted conduct. The limited experience of the Treaty on Outer Space, a multilateral agreement that attempts to control arms and military activities by relying on the term "peaceful purposes" while providing no clarifying rules or criteria, suggests that such an indeterminate approach in this area is highly problematic. ${ }^{220}$

${ }^{213}$ Id. Each state party to the BWC undertakes in Article VI, paragraph 2, "to cooperate in carrying out any investigation which the Security Council may initiate, in accordance with the provisions of the Charter of the United Nations, on the basis of the complaint received by the Council."

$214 \mathrm{Id}$

215 SC Res. 1540 (Apr. 28, 2004).

216 See Abbott \& Snidal, supra note 17 , at 427.

${ }^{217} I d$. (noting that legal review in the context of agreed rules and procedures is also more likely to increase the reputational costs associated with violations).

${ }^{218}$ See, e.g., David Kennedy, A New Stream of International Law Scholarship, 7 WIS. INT'L L.J. 1 (1988). Kennedy further argues that international law has become obsessively process oriented and inappropriately state centered when in fact the state might be better viewed as a "linguistic relationship between law and politics." Id. at 2, 49; see also DAVID KENNEDY, THE DARK SIDES OF VIRTUE: REASSESSING INTERNATIONAL HUMANITARIANISM (2004).

219 See FRANCK, supra note 101, at 53, 56-57.

220 See BIN CHENG, STUDIES IN INTERNATIONAL SPACE LAW 513-22 (1997). Cheng describes definitional problems related to the phrase "for peaceful purposes only" in Article IV of the Outer Space Treaty as giving rise to "grave anxiety." Id. at 513. The United States has chosen to interpret "peaceful purposes" in this Treaty as meaning "non-aggressive" (rather than "non-military"), an expansive view that leaves the door open to controversies over 
Although achieving a higher degree of rule determinacy in the BW context is not a simple task because of the difficulty of distinguishing between some offensive and defensive or "peaceful" BW activities, broad differences between related BW programs can be identified and key elements that are common to offensive programs can be subjected to restrictions or special scrutiny through appropriate transparency measures. ${ }^{221}$ Four areas for which such criteria and rules could be established are large-scale dissemination trials of BW agents, large-scale BW production activities, work on BW delivery systems, and efforts to enhance the potency of pathogens. ${ }^{222}$ Inside these four areas, "bright lines" could be drawn setting forth specific restrictions and transparency measures for certain activities or items, including the size or volume of certain types of equipment necessary to produce pathogens (such as fermenters and centrifugal separators), the quantity of certain types of manufacturing materials (such as the media needed to grow pathogens), and the research equipment and facilities necessary for developing BW delivery systems (such as aerosol inhalation chambers, spraying and fogging systems, and aerosolgenerating units). ${ }^{223}$

While not without challenges, lines could be drawn between key prohibited BW activities and permitted peaceful biotechnological activities, allowing mechanisms to be established to monitor compliance by using determinate rules and requirements that incorporate these distinctions. Critics of such an approach argue that even measures that incorporate clearer rules and requirements will not be effective in verifying compliance or in deterring violations by the most determined cheaters. Foremost among these critics are U.S. government officials who opposed the monitoring provisions in the BWC draft protocol on those grounds. ${ }^{224}$ Incongruously, some of these same officials had previously expressed support for such measures to

the defensive nature of weapons and military activities, and one that Cheng describes as "needless, wrong, and potentially noxious." Id. at 520 . Article IV does, however, provide the following clarifying language: "The establishment of military bases, installations and fortifications, the testing of any type of weapons and the conduct of military manoeuvres on celestial bodies shall be forbidden." Treaty on Principles Governing the Activities of States in the Exploration and Use of Outer Space, Art. IV, Jan. 27, 1967, 18 UST 2410, 610 UNTS 205. The limiting term "peaceful purposes" in the Antarctic Treaty similarly has the potential to raise definitional concerns, although Article I of that Treaty prohibits "any measures of a military nature" and further provides that specific prohibitions set forth in that agreement are, as Cheng explains, "exemplificative and not exhaustive." Antarctic Treaty, Art. I, Dec. 1, 1959, 12 UST 794, 402 UNTS 71; CHENG, supra, at 517.

In spite of attempts to establish parameters for the term "peaceful purposes," both the Antarctic and Outer Space Treaties also contain potentially problematic exemptions for these clarifying elaborations in subsequent provisions. See Antarctic Treaty, supra, Art. I (2) (providing: "The present Treaty shall not prevent the use of military personnel or equipment for scientific research or for any other peaceful purpose."); Outer Space Treaty, supra, Art. IV (providing: "The use of military personnel for scientific research or for any other peaceful purposes shall not be prohibited.").

${ }^{221}$ See Graham S. Pearson, Biological Weapons: Their Nature and Arms Control, in NON-CONVENTIONALWEAPONS PROLIFERATION, supra note 122, at 99, 117 (noting that "the depth of understanding and the scale of work has to be much greater to support an offensive programme"). Subjecting key elements of offensive BW programs to restrictions or special scrutiny does not require, and should not be used to promote, the establishment of lists or definitions of types or quantities of permitted biological agents or toxins, since such an action could be used to undermine the scope of the BWC's general prohibitions.

${ }^{222}$ See D. L. Huxsoll et al., Medicine in Defense Against Biological Warfare, 262 J. AM. MED. Ass'N 677 (1989), cited in Pearson, supra note 221, at 294. An initial attempt to establish rules based in part on these key elements was made, unsuccessfully, in the BWC draft protocol.

${ }^{223}$ These and other useful potential restrictions are suggested by the Australia Group's existing control lists and could serve to clarify not only what is prohibited under the BWC but also what is appropriate for exchange and transfer. See infra notes 251-56 and corresponding text.

${ }^{224}$ See Bolton, supra note 83; Mahley, supra note 80 (stressing that the "draft Protocol will not improve our ability to verify BWC compliance"). 
Congress, stating that effective verification was never the goal of the BWC draft protocol, but rather "greater transparency" in "dual-capable activities and facilities," and that there was "real value" in increased transparency measures that could "complicate the efforts of countries to cheat on their BWC obligations." 225

Prior to the U.S. invasion of Iraq, some commentators and U.S. government officials pointed to the failure of UN inspections in Iraq as evidence of the futility of monitoring efforts in deterring the development of BW and other WMD programs by a rogue state. There is now some irony in these arguments in light of the U.S. government's own findings (subsequent to the invasion) indicating that these and other UN activities did in fact contribute to impeding or complicating the development of Iraqi BW programs. ${ }^{226}$ Furthermore, while some nascent $B W$ research activities may be difficult to detect even with determinate rules and transparency measures, that is not true of the later stages of BW research and production and the integration of these weapons in to military strategy and training. ${ }^{227}$ On balance, while no design elements can ensure that resolute cheaters will not violate the BWC regime, determinacy and transparency together can significantly contribute to promoting the regime's objectives, improving its effectiveness, and making cheating more difficult and more detectable.

\section{INDETERMINATE ARMS CONTROL REGIMES AND COMPLIANT AND CONFORMIST STATES}

\section{Perceived Discriminatory Effect on Developing Countries}

To advance the complete elimination of a class or type of weapon, multinational disarmament regimes strive to achieve universal membership and attract nonstates parties that are acting in conformity with the regime's obligations. Persuading these "conformist states" to join a regime formally and become compliant states parties may be impeded by the effect of indeterminacy on the attractiveness of membership. On one level, the real, alleged, and feared defections that characterize the failure of a legally binding multinational disarmament regime dependent on soft indeterminate terms and soft structure, that is, one lacking transparency mechanisms, may make that regime less attractive generally. On another level, many developing states that have no interest in the weapons banned by a particular regime may also have little

\footnotetext{
${ }^{225}$ Donald A. Mahley, Testimony, Biological Weapons Convention, in Hearing Before the Subcomm. on National Security, Veterans Affairs and International Relations of the House Comm. on Government Reform, 106th Cong. (2000), available in LEXIS, Transcripts Library, Fed. Doc. Clearing House File, available at <http://www.fas.org/ spp/starwars/congress/2000_h/testimony_of_ambassador_donald_a.htm >. But see Barbara Hatch Rosenberg 8 Gordon Burck, Verification of Compliance with the Biological Weapons Convention, in PREVENTING A BIOLOGICAL ARMS RACE, supra note 49, at 300, 305 (noting that while no BWC verification regime will detect all violations, "[a]dequate verification will deter violation of the Convention, make illegal actions difficult and limit their scale, and provide workable means for international investigation of concerns that may be raised through national intelligence").

226 See, e.g., 3 CLA COMPREHENSIVE REPORT, supra note 124, at 39 (noting that as early as 1992, UN sanctions, inspections, mandatory declarations, and monitoring of the importation and use of media needed for the growth of bacterial BW agents created "impediments for any Iraqi biological production effort").

${ }^{227}$ Rosenberg \& Burck, supra note 225, at 304 (arguing in addition that the difficulties in monitoring BW activities at the research level have been overstated).
} 
interest in becoming bound by its obligations. ${ }^{228}$ These states may also believe that such a regime could have a negative effect on their access to dual-use technologies and other materials. Just as powerful egoist states are unlikely to join a regime that does not advance their security interests, so other states are unlikely to join unless the regime provides incentives for conscientious potential members to participate and fully comply with its obligations. ${ }^{229}$

While some suggest that not much is learned from empirical evidence of compliant behavior by states like Benin and Burkina Faso under a regime like the Outer Space Treaty, the unwillingness of many developing states to become parties to certain multilateral disarmament regimes may tell us something about the impact of indeterminate and interdependent provisions on the attractiveness of those regimes to such states. Powerful states may encourage less developed states to join disarmament regimes by promising them the widest possible access to dual-use technology and materials for peaceful purposes, in exchange for their abiding by related restrictions on weapons-related uses. Yet powerful nations may also treat the indeterminate terms of a disarmament regime as flexible and expansive so that they can pursue questionable bioweapons research while treating those terms as hard, narrow, and restrictive when it comes to attempts by developing states to gain access to restricted dual-use technologies.

By thus having it "both ways," powerful states may make a regime vulnerable to complaints by developing states that it discriminates against them by imposing obligations that are not coterminous with their disarmament responsibilities. Such perceived discriminatory conduct, in turn, may undermine the developing world's support for a regime and impede efforts to achieve universal membership by discouraging conformist nonsignatory states and compliant signatory states from taking the actions necessary to join or become full states parties.

\section{Compliant and Conformist States and the BWC}

Currently, 155 of the 192 member states of the United Nations are parties to the BWC. ${ }^{230}$ Relatively few of them have ever been alleged to be states of BWC concern and thus almost all of them can generally be described as compliant parties. ${ }^{231}$ An additional 16 states have signed the BWC but have not yet ratified it or otherwise taken the necessary steps to become parties. ${ }^{232}$ Most of these states are also widely regarded as complying with their BWC obligations: only Egypt and

\footnotetext{
${ }^{228}$ Compliant signatory states in the developing world that have not yet completed the formal processes necessary to become parties to disarmament regimes, like conformist nonsignatory states, may find full membership in such regimes unattractive.

${ }^{229}$ KEOHANE, supra note 156, at 103 ("Insofar as regimes create incentives for compliance, they also make it more attractive for conscientious potential members to join them.").

230 See Status of Multilateral Arms Regulation and Disarmament Agreements, at $<$ http://disarmament2.un.org/ TreatyStatus.nsf $>$. A state that is not a member of the United Nations, the Holy See, is a party to the BWC. Id.

${ }^{231}$ Even U.S. officials quick to allege violations by other states have conceded that "the vast majority of the BWC's parties have conscientiously met their commitments." John R. Bolton, Beyond the Axis of Evil: Additional Threats from Weapons of Mass Destruction, Remarks to the Heritage Foundation (May 6, 2002), available at <http://www.state.gov/t/us/rm/9962.htm>.

${ }^{232}$ The 16 states that have signed the BWC but not yet become parties are Burundi, the Central African Republic, Côte d'Ivoire, Egypt, Gabon, Guyana, Haiti, Liberia, Madagascar, Malawi, Myanmar, Nepal, Somalia, Syria, Tanzania, and the UAE. See Status of Multilateral Arms Regulation and Disarmament Agreements, supra note 230. As signatories, these states are obliged to refrain from acts that would defeat the object and purpose of the BWC pending their ratification, acceptance, or approval of the Convention or until it "shall have made its intention clear not to become a party to the treaty." See Vienna Convention on the Law of Treaties, Art. 18(a), May 23, 1969, 1115 UNTS 331. There are currently 108 states parties, including Egypt, Syria, and 5 other BWC signatory states.
} 
Syria have been alleged to be of BW concern. ${ }^{233}$ Of the 21 nonsignatory states, only Israel has been alleged to be of BW concern. ${ }^{234}$ The remaining 20 states are generally regarded as conformist nonsignatories, states that do not have BW programs and do not appear to be pursuing them. ${ }^{235}$

Almost all of the 20 apparently compliant nonsignatory states are poor, fragile, or economically distressed, and most are classified among the least-developed or poorest countries of the world. ${ }^{236}$ Most of the 14 apparently compliant BWC signatory states also fall into that category. ${ }^{237}$ Both of these groups of states may have more incentives to adopt preferences related to economic and technical development than to the acquisition of a new, uncertain, and expensive unconventional weapons capability. ${ }^{238}$ While unlikely to be interested in BW programs, these states are also no longer moved by any of the incentives to join the BWC based on affiliation with one of the two camps of Cold War adversaries. Uninterested in biological weapons but unmotivated to become a party to the BWC, these poor or fragile states nonetheless prevent the BWC regime from achieving universality.

In recent years, few states have ratified or acceded to the BWC. ${ }^{239}$ Beyond the considerations listed above, two other factors that are linked to the failure of indeterminate regimes in acute security dilemmas are likely to contribute to this apparent lack of motivation. First, the BWC regime can be described as unattractive to possible new members because of its widely perceived failure to address noncompliance issues and the continuing failure of the states parties to make necessary reforms. Second, developing states may find the BWC regime unatractive because they perceive the regime's indeterminate and interdependent provisions as having a discriminatory impact on their access to health care and biotechnology resources. Most of the developing states that remain outside the BWC not only have limited financial resources but also would probably prefer to obtain access to vaccines, diagnostic equipment, advanced biotechnology, and various pharmaceutical products than to join a treaty regime that does not improve — and may be viewed as impeding - their access to health sciences and biotechnology.

${ }^{233}$ See supra note 85.

${ }^{234}$ The 21 members of the United Nations that have not signed the BWC are Andorra, Angola, Cameroon, Chad, the Comoros, Djibouti, Eritrea, Guinea, Israel, Kazakhstan, Kiribati, the Marshall Islands, Mauritania, Micronesia, Mozambique, Namibia, Nauru, Samoa, Trinidad and Tobago, Tuvalu, and Zambia. See Weapons of Mass Destruction, at <http://disarmament.un.org/wmd/>.

${ }^{235}$ See supra note 85 . One nonsignatory, Kazakhstan, is not generally regarded as a state of BW concern but is one of several states that inherited a significant amount of BW infrastructure from the former Soviet Union. See generally SMITHSON, supra note 69.

236 Twelve of the 21 BWC nonsignatory states are listed by the United Nations as "least developed countries." See UN Office of the High Representative for the Least Developed Countries, List of Least Developed Countries, at <http://www.un.org/special-rep/ohrlls/ldc/list.htm> [hereinafter LDC List]. An additional 5 are listed in the World Bank's lowest two of five categories of economic development. See World Bank, Data and Statistics (2007), at <http://www.worldbank.org/countries> [hereinafter World Bank Data].

237 Ten of the 16 BWC signatory states are listed by the United Nations as least-developed countries. See LDC List, supra note 236. An additional 4 are listed in the World Bank's lowest two of five categories of economic development. See World Bank Data, supra note 236.

${ }^{238}$ Contrary to a view popularized in Western countries, the advanced science and technology required for $\mathrm{BW}$ programs make biological weapons an unlikely component in the arsenals of developing countries. See Wright, supra note 55, at 6 (finding "some irony" in describing biological weapons as the "poor man's nuke" in view of their development by industrialized countries).

${ }^{239}$ Only 12 UN member states have become parties to the BWC since 2000. See Status of Multilateral Arms Regulation and Disarmament Agreements, supra note 230. All of the 16 signatory states that have failed to com- 
As seen above, despite arguments that soft law facilitates wider participation in regimes and more easily permits reluctant states to join and comply with regime requirements, ${ }^{240}$ soft indeterminate provisions in legally binding agreements like the BWC may have the opposite effect for developing states. The ambiguities in Article I permit powerful industrial states to advance their own security interests by undertaking questionable BW research activities for "prophylactic, protective or other peaceful purposes," while broadly prohibiting the exchange of various dual-use materials through export controls coordinated by the Australia Group (AG). ${ }^{241}$ Although developing countries enjoy the right under Article $\mathrm{X}$ to "the fullest possible exchange of equipment, materials and scientific and technological information for the use of bacteriological (biological) agents and toxins," 242 in practice the developed industrial states have used the indeterminate conditional phrase "for peaceful purposes" in that article to justify the imposition of whatever AG-coordinated restrictions they deem appropriate on the transfer and export of dual-use materials, technology, and information. AG member states argue that these export controls merely implement Article III of the BWC by preventing the transfer of any of the agents, toxins, weapons, equipment, or means of delivery specified in Article I. ${ }^{243}$ However, no rules or criteria established collectively by BWC states parties inform this implementation process.

Although Article X further requires that the BWC be "implemented in a manner designed to avoid hampering the economic or technological development of States Parties to the Convention," this requirement again applies only to indeterminate "peaceful bacteriological (biological) activities." ${ }^{444}$ For purposes of export control, the AG has turned interdependent and vague terms in the BWC into precise national rules by imposing standardized end-user undertakings through common lists of export-controlled biological agents and dual-use biotechnology. Developing states argue that many of the prohibited items on these lists are necessary for disease control and public health improvements and that $A G$ export control measures are applied in a discriminatory manner, contravening their rights under the BWC to the free exchange of materials, technology, and expertise. ${ }^{245}$

Advanced industrial states thus exploit the interdependent term "peaceful purposes" so that it remains indeterminate and flexible when applied against them under Article I but specific

plete the necessary procedures to become a member of the BWC originally signed the Convention in 1972 or 1973 immediately after it was opened for signature. Id.

${ }^{240}$ Shelton, supra note 13, at 319; pt. V, "Perceived Discriminatory Effect on Developing Countries," supra.

${ }^{241} \mathrm{BWC}$, supra note 1, Art. I(1). The AG is an informal consultative arrangement of states that was founded in 1984 after events in the Iran-Iraq war revealed that some countries were producing chemical weapons with materials obtained through international trade and a lack of uniform licensing measures. The AG first sought to impede the proliferation of chemical weapons through coordinated national export control laws and later expanded its mandate to include biological weapons. All thirty-eight states that participate in the AG are parties to the BWC and the CWC and include most of the states of the world with advanced biological and biotechnology industries. See AG, Origins of the Australia Group, at <http://www.australiagroup.net>.

${ }^{242}$ BWC, supra note 1 , Art. X(1).

${ }^{243}$ See AG, Objectives of the Group, at <http://www.australiagroup.net>.

${ }^{244}$ BWC, supra note 1 , Art. X(2).

${ }^{245}$ See, e.g., Sha Zukang, head of the Chinese Delegation, Statement to the Fifth Review Conference of the States Parties to the BWC (Nov. 19, 2001), available at BWC Web site, supra note 7 , at 3 (criticizing advanced countries for "stubbornly sticking to existing discriminatory practices" that were "detrimental . . . to the legitimate rights of states parties"); John Zarocostas, Gaps Remain in Weapons Ban Talks, UPI, Feb. 23, 2001, available in LEXIS, Wire Service Stories Library. 
and hard when broadly applied through export controls against developing states under Articles III and X. Besides being widely perceived as discriminatory, this practice cannot advance the achievement of universality. ${ }^{246} \mathrm{It}$ arguably also creates incoherence, which undermines the legitimacy of the BWC regime itself. ${ }^{247}$ Current BWC states parties in the developing world that participated in the Ad Hoc Group emphasized these concerns by showing less interest in the draft protocol's verification measures than in its attempts to establish lines distinguishing the types of equipment and materials that are-and are not-properly subject to transfer restrictions under the Convention. ${ }^{248}$ Without more determinate language to draw such lines, developing states parties attempting to import biotechnological and pharmaceutical materials for peaceful purposes will continue to face restrictions that are not coterminous with the problem of biological weapons, creating a confrontational situation that over time will be hard to contain under a multilateral disarmament agreement. ${ }^{249}$ For developing nonparty states, the rational mechanisms associated with the BWC's indeterminate and interdependent terms are likely to perpetuate their perception of the BWC's discriminatory application, fueling their disincentives to participate in the regime.

\section{Hard Solutions for the BWC: Applying Determinacy to Compliant and Conformist States}

The problems for compliant and conformist nonparty states that are caused by the discriminatory application of indeterminate terms in the BWC cannot be solved by the Western approach of using different definitions for the same language in key articles, since developing and many other states clearly view these articles as inseparably linked. ${ }^{250}$ Instead, determinacy in the BWC framework, in conjunction with greater transparency, has the potential to resolve this problem by allowing developing states greater access to technology and materials that are not subject to BWC regulation, while at the same time clarifying restrictions on prohibited activities. Some determinate, line-drawing solutions to perceived BWC discrimination problems are suggested by the Australia Group's own codification efforts. From the perspective of

246 See, e.g., Rakesh Sood, head of Delegation of India, Statement to the Fifth Review Conference of the States Parties to the BWC (Nov. 20, 2001), available at BWC Web site, supra note 7, at 5 ("The promotional aspects of Article $\mathrm{X}$ are, we believe, a crucial element in strengthening the Convention and even perhaps in achieving universal adherence.").

247 See FRANCK, supra note 101, at 153

248 See Oliver Thränert, Enhancing the Biological Weapons Convention, in ENHANCING THE BWC, supra note 145, at 17 (further noting that many African countries perceive greater threats from diseases like HIV and Ebola than from BW programs); Zarocostas, supra note 245 (quoting Ambassador Tibor Tóth, chairman of the Ad Hoc Group, as saying that export controls "were debated in a heated manner," with emphasis by developing countries on the need for access to technology related to diseases).

${ }^{249}$ See Chayes \& Shelton, supra note 30, at 525 ("Long-term stability and efficiency require that arms control regimes be built upon mutual interests and relationships, not confrontation.").

250 See Celina M. Assumpçao de Valle Pereira, ambassador, Statement to the Fifth Review Conference of the States Parties to the BWC (Nov. 19, 2001), available at BWC Web site, supra note 7 (describing nonproliferation and technological cooperation as viewed as the "two main pillars" of the BWC); Sood, supra note 246, para. 7 (describing Articles III and X as "two mutually inseparable aspects of any disarmament agreement that deals with a dual-use technology"); Sha Zukang, supra note 245, at 3 (arguing that nonproliferation activities and the promotion of peaceful uses of biotechnology "should be complementary and mutually reinforcing," while noting with regret that "a minority of countries have gone out of their way to separate the two issues"); Abdul Basit, acting permanent representative of Pakistan, Statement to the Fifth Review Conference of the States Parties to the BWC (Nov. 19, 2001), available at BWC Web site, supra note 7, para. 10 (emphasizing that Pakistan "cannot agree to an interpretation of Article III that is in any manner at variance with the provisions of Article X"). 
many developing and other states that seek fully to implement the free exchange of technology envisioned in the BWC, certain types of protective and containment equipment listed as AG-controlled items have important applications for public health. ${ }^{251}$ From the perspective of powerful states that already benefit from advanced biotechnology and are more interested in security, the export of such items to developing states would be less problematic if it were covered by mandatory transparency measures such as some form of monitoring requirements.

Unlike protective equipment, however, other types of AG-controlled items appear to be more useful for BW programs than for disease control or peaceful medical activities, particularly when quantitative requirements and rules are applied. These items include fermenters with specified high capacities, ${ }^{252}$ centrifugal separators with specified capabilities including high flow rates, ${ }^{253}$ aerosol inhalation chambers with specified high capacities, ${ }^{254}$ and other items necessary for the development of BW delivery systems such as spraying and fogging systems and aerosol-generating units. ${ }^{255}$ Thus, many items on the AG-controlled list were logically included on mandatory declaration lists in the final composite text of the BWC draft protocol. 256

While bringing determinacy and consistency to the BWC through more precise technological specifications presents challenges, the common items of equipment that appear on both the AG-controlled list and the mandatory declaration list of the draft protocol suggest that the BWC states parties could collectively agree on at least some types of equipment that should be subject to prohibitions or increased scrutiny under Article I and to denial of transfer or export under Articles III and X. The establishment of monitoring mechanisms could give AG member states corresponding incentives to abandon their conflicted approach to several items they find acceptable for themselves yet not for transfer or export to other states. From the self-interested perspective of these developed states, the continued use of only their own guidelines to prohibit transfers (rather than a complementary and collective agreement by BWC states parties on critical ambiguous terms) continues to risk undermining the disarmament regime they seek to reinforce. ${ }^{257}$ While powerful states can be expected to pursue their own interests, AG member

${ }^{251}$ Protective and containment equipment includes complete containment facilities (at the "containment" or "maximum containment," known as the P3 and P4, levels, as specified by the WHO) and various types of protective suits and biological safety cabinets or isolators. AG, Control List of Dual Use Biological Equipment and Related Technology, \$\$I.1, I.6 (Apr. 2005), at <http://www.australiagroup.net>.

252 Id. $\$ I .2$.

253 Id. $\$ \mathrm{I} .3$.

254 Id. \$I.7.

${ }^{255} \mathrm{Id}$. $\$$ I.8. Other items of concern that seem unlikely to be used primarily for peaceful civilian activities have been included on AG-controlled lists so as to raise the awareness of the industry, including equipment for the microencapsulation of live microorganisms and toxins in the range of one to ten microns particle size; fermenters that have small capacities but are part of aggregate orders or are designed for use in combined systems would similarly justify special treatment. Id., Items for Inclusion in Awareness Raising Guidelines, paras. 1-2.

${ }^{256}$ For example, each state party with specified facilities would have been required under the protocol to declare production of designated agents using bioreactors/fermenters with total internal volume of 50 liters or more, see Protocol to the BWC, supra note 79, at 19-20, and would also have been required to supply information concerning various other types of equipment present at or used in a declared facility, including specified types of continuous or semicontinuous centrifuges with throughput capacity greater than 100 liters per hour, see $i d$. at 118 .

${ }^{257}$ BWC developing states strongly criticize this extraregime regulatory approach, arguing that "the transfer of dual-use materials for medical, diagnostic and treatment purposes should be regulated on the basis of guidelines to be negotiated and accepted by all States Parties." See Sood, supra note 246, para. 7. For its part, the 
states may be taking a myopic view of those interests by not seeking to clarify these key ambiguities, by maintaining BW export control lists outside the BWC regime, and, in the case of the United States, by opposing a legally binding BWC monitoring regime that also attempts to establish some determinate rules and requirements. ${ }^{258}$

In view of the probable scant interest of most compliant and conformist nonparty states in joining the BWC, the scarcity of their resources for engaging in major disarmament initiatives, and their likely competing preferences, the question arises of the willingness of such states to embrace a reformed BWC regime even with the inclusion of determinate provisions. The experience of other regimes may shed some insight on this question. Twenty-four of the thirty-one poorest developing countries that are not parties to the BWC have nonetheless expended scarce governmental resources and shown sufficient interest in limiting the spread of WMDs to become parties to the CWC, and all thirty-one have become parties to the NPT. ${ }^{259}$ Like the BWC, both are multilateral disarmament agreements that address access to complex dual-use technology and materials capable of generating acute security dilemmas.

That all but seven of the thirty-one developing states that have not become parties to the BWC over the last forry years have chosen to join the CWC regime since it was opened for signature in 1997 may reflect various calculations and assessments, but calls particular attention to the more determinate rules of the CWC and its developed oversight and monitoring mechanisms. ${ }^{260}$ While the regulation of materials and technology related to biological weapons presents a number of challenges, the success of the more recently established CWC regime at least suggests that the BWC's relative lack of determinacy - the absence of rules, schedules, or criteria for distinguishing peaceful biotechnology from prohibited BW programs-is not the inevitable result of these challenges. ${ }^{261}$

United States has argued that the guidelines in the draft protocol "could undermine U.S. regulations against the export of sensitive technology used in bioweapons." Glenda Cooper, U.S. Rejects Biological Arms Ban Protocol, WASH. POST, July 26, 2001, at A1. Some arms control experts, however, have questioned why the draft protocol's clearer requirements for export controls would undermine AG efforts rather than support them. See Brugger, supra note 86.

258 "Myopic" self-interest refers to a state's perception of the relative costs and benefits of alternative available courses of action with respect to a particular issue when the assessment of that issue is made in isolation from others. KEOHANE, supra note 156, at 99. The apparent anomaly of egoistic states acting in ways that appear to be inconsistent with their interests may often be explained by the fact that they are complying with rules that conflict with their immediate or "myopic" self-interests. Id.

${ }^{259}$ See Status of Multilateral Arms Regulation and Disarmament Agreements, supra note 232. Only one state, Angola, has signed neither the CWC nor the BWC; two other BWC nonparties, the Comoros and Israel, have signed but not yet ratified the CWC. Id. As noted above, thirty-one of the thirty-seven UN member states that are not parties to the BWCare designated as least-developed countries by the United Nations or are in the World Bank's bottom two categories of economic development. See LDC List, supra note 236; World Bank Data, supra note 236. Yet only seven of these poorest developing states (Angola, the Central African Republic, the Comoros, Egypt, Myanmar, Somalia, and Syria) are not parties to the CWC. See Status of Multilateral Arms Regulation and Disarmament Agreements, supra note 232.

${ }^{260}$ See infra text at notes $280-85$.

${ }^{261}$ Mikhail Berdennikov, special advisor to the director-general, The Experience of the Organization for the Probibition of Chemical Weapons, in THE IMPLEMENTATION OF LEGALLY BINDING MEASURES TO STRENGTHEN THE BIOLOGICAL AND TOXIN WEAPONS CONVENTION 103, 107 (Marie Isabelle Chevrier et al. eds., 2004) [hereinafter IMPLEMENTATION OF LEGALLY BINDING MEASURES]; Graham S. Pearson, The Key Elements of a Legally Binding Instrument to Strengthen the Biological and Toxin Weapons Convention, in id. at 55, 77 ("A comparison of the BW TC legally binding instrument regime and the CWC regime has shown that the two regimes are indeed comparable and effective."). 


\section{CONCLUSION}

A brief review of other multilateral disarmament regimes that must address the instability generated by easily confused military and civilian applications of regulated technology indicates that such regimes rely increasingly as they mature on harder language-namely, more determinacy-and harder structures-namely, legally binding verification and transparency measures - to ensure the clarity of fundamental obligations under the regime. The regulation of nuclear weapons under the NPT offers a case in point. The NPT is a legally binding agreement that, among other things, obligates non-nuclear weapons parties not to acquire such weapons and requires international inspections of all their nuclear activities to verify compliance and ensure the peaceful use of any nuclear materials. ${ }^{262}$ Just as the BWC guarantees various rights with respect to peaceful uses of regulated dual-use materials, so the NPT affirms an "inalienable right of all the Parties to the Treaty to develop research, production and use of nuclear energy for peaceful purposes" and guarantees the "fullest possible exchange of equipment, materials and scientific and technological information for the peaceful uses of nuclear energy." ${ }^{263}$ As under the BWC, some NPT-regulated materials may have both military and peaceful applications, increasing the risk of defensive defections based on misperceived threats. The high security stakes at issue in the NPT and the "prestige" and power associated with nuclear weapons also present temptations for offensive defectors, and this temptation is not reduced by the status that several powerful countries continue to enjoy as nuclear weapons states under the NPT. ${ }^{264}$ Structures and measures to identify and detect cheating are thus design elements for an effective NPT regime.

Specific procedures and detailed requirements designed to ensure verification of the fulfillment of a state's obligations under the NPT are incorporated into the legally binding comprehensive safeguards agreement that each non-nuclear weapons party is required to negotiate with the International Atomic Energy Agency (IAEA). ${ }^{265}$ As the NPT has matured, the IAEA has "hardened" the regime's transparency requirements by continually extracting deeper and more precise commitments from member states through legally binding additional protocols that are designed to reinforce the safeguards agreements. ${ }^{266}$ The IAEA developed the Model Additional Protocol in 1997 in response to Iraq's successful concealment of its pre-1991 nuclear program. ${ }^{267}$

${ }^{262}$ NPT, supra note 202, Arts. II, III.

${ }^{263}$ Id., Arr. IV(1), (2).

${ }^{264}$ Unlike biological weapons, nuclear weapons are widely viewed as an effective strategic deterrent and have become an integral part of the security policies of NPT nuclear weapons states parties. Moreover, biological weapons are less likely to inspire the "ferocious nationalistic pride" that nuclear weapons and energy generate in some states. See Christopher Dickey et al., Iran's Rogue Rage, Nukes: Iranians Want Nuclear Know-How-and Seem to Be Daring the West to Stop Them, NEWSWEEK, Jan. 23, 2006, at 26, 26.

${ }^{265}$ The IAEA is a UN-related organization whose safeguards system is intended to verify NPT compliance. As of March 22, 2007, thirty-one NPT non-nuclear weapon states had not yet brought into force a comprehensive safeguards agreement with the IAEA. NPT Comprehensive Safeguards Agreement: Overview of Status (Mar. 22, 2007), at <http://www.iaea.org/Publications/Factsheets/English/nptstatus_overview.html>.

${ }^{266}$ One hundred and eleven UN member states have signed additional protocols and seventy-seven are currently in force; a protocol with Iran is being implemented pending its formal entry into force, although Iran recently curtailed most access to its facilities. See id.

267 See LAEA Staff Reports, More States Sign Safeguards Agreements and Additional Protocols (Nov. 28, 2005), available at $<$ http://www.iaea.org/NewsCenter/News/2005/safeguardsrights.html $>$. 
In the case of Iran's controversial uranium enrichment and reprocessing activities and related deceptive practices, the LAEA has sought more detailed and precise information and an even more comprehensive level of access than is required by the safeguards agreement and additional protocol. ${ }^{268}$ Such additional detailed transparency and verification measures form a critical part of the maturing and hardening of the NPT regime as it has continued to attract new members: only 4 of the 192 members of the United Nations are nonparties to the NPT and remain outside its legally binding obligations. ${ }^{269}$

Even as the NPT has progressively become harder, the regime has suffered setbacks in some important cases where the IAEA has relied on both nonlegally binding instruments and indeterminate language. For example, after years of failing to meet its obligations under its safeguards agreement, ${ }^{270}$ the Iranian government was nonetheless initially able to escape referral by the IAEA to the UN Security Council for its apparent NPT violations in September 2003 by agreeing merely to a vague nonbinding statement that it would voluntarily suspend its suspect uranium enrichment and processing activities. ${ }^{271}$ On January 10, 2006, Iran reneged on this nonbinding commitment and announced that it had broken the internationally monitored seals at its nuclear sites and would resume "research activities" with equipment that included centrifuges capable of enriching uranium for use in a nuclear bomb. ${ }^{272}$ On June 6, 2006, the five permanent members of the Security Council and Germany offered Iran a package of incentives accompanied by an array of possible penalties aimed at persuading it to freeze some of its most important questionable nuclear activities. ${ }^{273}$ After Iran rejected a proposed incentives package and refused to halt its enrichment and reprocessing activities, the UN Security Council, on July 31, 2006, adopted a resolution calling on Iran to

268 The IAEA Board of Governors urged Iran to adopt these additional transparency measures on September 24, 2005, noting that "Iran's full transparency is indispensable and overdue." IAEA Res. GOV/2005/77, pmbl., para. 4 (Sept. 24, 2005), at <http://www.iaea.org/Publications/Documents/Board/2005/gov2005-77.pdf>. Subsequent board resolutions have continued to stress the need for Iran to implement all required transparency measures and support ongoing board investigations. See, e.g., IAEA Res. GOV/2006/14 (Feb. 4, 2006), at <http://www. iaea.org/Publications/Documents/Board/2006/gov2006-14.pdf $>$. The UN Security Council has repeatedly affirmed that Iran must comply with IAEA Res. GOV/2006/14 in order "to build confidence in the exclusively peaceful purpose of its nuclear programme and to resolve outstanding questions." SC Res. 1696, para. 1 (July 31 , 2006); SC Res. 1737, para. 1 (Dec. 27, 2006); SC Res. 1747, para. 1 (Mar. 24, 2007).

269 India, Israel, and Pakistan have not signed the NPT; North Korea joined the NPT in 1985, but in January 2003 announced its intention to withdraw. See Status of Multilateral Arms Regulation and Disarmament Agreements, supra note 230 .

${ }^{270}$ LAEA Director General, Implementation of the NPT Safeguards Agreement in the Islamic Republic of Iran, IAEA Doc. GOV/2005/67 (Sept. 2, 2005), at <http://www.iaea.org/Publications/Documents/Board/2005/ gov2005-67.pdf $>$ (detailing how over many years Iran had failed to meet its obligations under its safeguards agreement by not reporting nuclear material, its processing, and its use; not declaring related processing and storage facilities; not providing design information; and engaging in "extensive concealment activities").

${ }^{271}$ Statement by the Iranian Government and Visiting EU Foreign Ministers, para. 2(b)(i) (Oct. 21, 2003), available at <http://www.iaea.org/NewsCenter/Focus/IaeaIran/statement_iran21 102003.shtml>. Iran's chief nuclear negotiator noted that Iran had "won a crucial change to reflect the fact that the freeze of its enrichment program was 'not legally binding.' " Elaine Sciolino, Iran Backs away from a Demand on A-Bomb Fuel, N.Y. TIMES, Nov. 29, 2004, at Al.

${ }^{272}$ Steven R. Weisman \& Nazila Fathi, Iranians Reopen Nuclear Centers, N.Y. TIMES, Jan. 11, 2006 , at A1.

${ }^{273}$ Nazila Fathi \& Elaine Sciolino, Iran Open to Incentives on Nuclear Talks, with a Hedge, N.Y. TIMES, June 7, 2006, at A14. Subsequent attempts by the European Union to work out an "incentives package" with Iran led to Iranian requests for specific details on "verification" and "sequencing." See Judy Dempsey, Iranian and Europe Envoy Open Talks on Uranium Enrichment, N.Y. TIMES, Sept. 28, 2006, at A14. 
suspend these activities. ${ }^{274}$ Confronted with Iranian defiance, the Security Council approved additional resolutions in December 2006 and March 2007, which imposed mild sanctions and threatened tougher ones if Iran continued to fail to comply with the Council's demands. ${ }^{275}$

As the Iranian nuclear crisis continues to unfold at the writing of this article, concerned NPT members face considerable risks and challenges in designing a supplemental framework to ensure that Iran will comply fully with regime requirements as it continues to engage in "peaceful" nuclear activities. Since Iran enjoys an "inalienable right" to the peaceful use of nuclear energy—which its leaders argue includes uranium enrichment processes that can produce both fuel for nuclear reactors and fissionable material for nuclear weapons - continuing efforts to persuade Iran to forgo that right are likely to involve proposed incentives, rewards, or compensation, in addition to the threat of possible sanctions.

The design of an incentives or compensation package to encourage Iran to comply with its NPT obligations and permit related inspections will probably require determinacy to establish the requisite behavior, the contours of the incentives, and the penalties involved. Both sides in such a transacrion appear to have a fundamental interest in ensuring determinacy, as demonstrated by the initial response of Iran's chief nuclear negotiator to the package of incentives and penalties proposed on June 6, 2006, when he expressed concern about the removal of some "ambiguities." 276

Another example of applied determinacy and transparency in a multilateral disarmament regime charged with the regulation of dual-use materials is the CWC. The CWC enjoys the benefit of a dedicated full-time oversight authority, the Organization for the Prohibition of Chemical Weapons (OPCW), ${ }^{277}$ as well as an elaborate verification regime containing mechanisms and procedures for conducting eleven different types of inspections that can take advantage of several reinforcing layers of determinate rules. In addition to obligations in the text, annexes to the CWC spell out, with as much clarity and precision as possible, critical definitions, guidelines, criteria, and schedules of chemicals to be used in regulating the elimination of chemical weapons. ${ }^{278}$ The CWC also contains an Annex on the Protection of Confidential Information and an Annex on Implementation and Verification, which establish various criteria and definitions pertaining to regulated equipment, buildings, and personnel. ${ }^{279}$

As with other regulated weapons, various incentives for defection by states from CW disarmament cooperation can easily be identified. For example, the military and civilian applications of many chemicals and their precursors may elicit misperceived threats and

\footnotetext{
${ }^{274}$ SC Res. 1696 (July 31, 2006). Iran failed to comply with the Council's sixty-day deadline for suspension of these activities. See Dafna Linzer \& Colum Lynch, Iran Continues Nuclear Work Despite Deadline, Sanction Threat, WASH. POST, Feb. 22, 2007, at A14.

${ }^{275}$ See SC Res. 1737 (Dec. 27, 2006) (prohibiting trade with Iran in nuclear materials and ballistic missiles and freezing financial assets of ten key Iranian entities and twelve individuals associated with these programs); SC Res. 1747 (Mar. 24, 2007) (banning all Iranian arms exports and freezing financial assets of fifteen Iranian individuals and thirteen entities linked to Iranian military and nuclear agencies).

${ }^{276}$ Fathi \& Sciolino, supra note 273.

277 The OPCW includes the Conference of States Parties, Executive Council, Technical Secretariat, Confidentiality Commission, and advisory boards on science and administrative and financial matters.

${ }^{278}$ An integral part of the CWC is a detailed Annex on Chemicals that includes Guidelines for Schedules of Chemicals. The guidelines in part I of the annex contain specific criteria for determining whether toxic chemicals or precursors should be included in one of three different schedules or levels of regulation in part II of the annex. These schedules identify chemicals for the application of extensive verification measures according to the provisions of the detailed Verification Annex. See CWC, supra note 158, Annex on Chemicals.

${ }^{279}$ See CWC, Annex on the Protection of Confidential Information; id., Annex on Implementation and Verification.
} 
defensive defections. In addition, unlike biological weapons, chemical weapons have a history of demonstrated military utility, particularly in some recent conflicts in the Middle East, and thus present a real risk that a state will cheat to gain a decisive military advantage. Unlike the BWC regime, the CWC regime has been forced to deal with weapons that in many cases were deployed in sizable numbers and often presented complex questions about their safe removal and disposal. ${ }^{280}$ In spite of the CWC's recent entry into force, the incentives for noncompliance, and the complexity and expense of safe and environmentally sound CW disposal, the regime has achieved striking success. The CWC has already attracted 179 UN members as states parties, and in the ten years since its entry into force in 1997 all $\mathrm{CW}$ production facilities declared by states have been inactivated, all declared $\mathrm{CW}$ stockpiles have been inventoried and verified, and 59 of the 65 declared $\mathrm{CW}$ production facilities have been either destroyed or converted for peaceful purposes. ${ }^{281}$ In addition, nearly twenty-eight hundred inspections have taken place at nearly two hundred $\mathrm{CW}$-related facilities and at over 850 industrial sites on the territory of 77 states parties. ${ }^{282}$ As the $\mathrm{CWC}$ regime matures and cooperation deepens, determinacy plays an increasingly important role in the success of inspections, the regulation of chemical agents, the elimination of $\mathrm{CW}$ stockpiles, and related assistance activities.

Although states have succeeded in making other multilateral disarmament regimes progressively harder, the collapse and failure of collective state action to reform the BWC has coincided with calls by some legal scholars to focus less attention on governmental actions and more on the role that individual scientists, businesses, trade organizations, academic groups, and other nongovernmental actors in civil sociery can play in preventing BW proliferation and in protecting human health and the environment. ${ }^{283}$ Consistently with the view that rejects states as primary and unitary actors in international affairs in favor of a disaggregated model that emphasizes the role of nonstate actors and the importance of transnational societal interaction, ${ }^{284}$ some commentators have suggested that the appearance of new and reemerging infectious diseases has demonstrated the limitations of Westphalian governance, ${ }^{285}$ while highlighting the growing significance of nonstate actors in a new framework of "global health

\footnotetext{
${ }^{280}$ David A. Koplow, How Do We Get Rid of These Things?: Dismantling Excess Weapons While Protecting the Environment, 89 NW. U. L. REV. 445, 451 (1995).

${ }^{281}$ See Status of Multilateral Arms Regulation and Disarmament Agreements, supra note 230; Organisation for the Prohibition of Chemical Weapons, Declarations and Inspections, and Chemical Weapons Destruction Under Way (Mar. 16, 2007), at <http://www.opcw.org/factsandfigures/index.html > (further noting that "[o]ver 30\% of the 8.6 million chemical munitions and containers covered by the Convention have been verifiably destroyed").

${ }^{282}$ Organisation for the Prohibition of Chemical Weapons, Declarations and Inspections, supra note 281.

${ }^{283}$ See Wright \& Falk, supra note 125, at 433 (arguing for "a heightened mobilization of global civil society" as with conclusion of the antipersonnel land mines treaty as only way to avoid a biological arms race); see also Kenneth Anderson, The Ottawa Convention Banning Landmines, the Role of International Non-governmental Organizations, and the Idea of International Civil Society, 11 EUR J. INT'L L. 91 (2000); Richard Price, Reversing the Gun Sights: Transnational Civil Society Targets Land Mines, 52 INT'L ORG. 613 (1998).

${ }^{284}$ See Anne-Marie Slaughter Burley, International Law and International Relations Theory: A Dual Agenda, 87 AJIL 205, 225 (1993); Andrew Moravcsik, Taking Preferences Seriously: A Liberal Theory of International Politics, 51 INT'L ORG. 513, 522 (1997); Anne-Marie Slaughter, A Liberal Theory of International Law, 94 ASIL PROC. 240 (2000).

${ }^{285}$ See generally David P. Fidler, SARS: Political Pathology of the First Post-Westphalian Pathogen, 31 J. L. MED. \& ETHICS 485 (2003).
} 
governance." ${ }^{286}$ In fact, transnational societal efforts to prevent BW proliferation continue to be pursued, including through codes of conduct for scientists, guidelines for corporations in the biopharmaceutical sector, and various other initiatives designed to provide more safety and security in biotechnology.

Notwithstanding their increasing importance in some areas, transnational societal efforts have made uneven progress across different fields of international cooperation ${ }^{287}$ and may be especially limited in the area of national security, where states play the dominant role and continue to develop dangerous weaponized pathogens on the basis of their own security-driven, self-interested preferences. Furthermore, many transnational societal efforts related to BW nonproliferation are affected by the large amounts of funding that governments now provide to universities, companies, and other nonstate actors for their participation in BW-related programs, including expansive and sometimes questionable biodefense programs. ${ }^{288}$ Their many financial and other interests may prevent these transnational societal efforts from being consistently or universally directed toward the same goals. ${ }^{289}$ One important group of nonstate actors that supports many transnational biosecurity and biosafery issues, the U.S. pharmaceutical industry, has also been a major force in opposing efforts to strengthen the BWC regime. In comments reflecting the concerns of this group, the U.S. government stated that it opposed the BWC draft protocol in part because it would negatively affect the pharmaceutical and biotech industries by putting "confidential business information at risk." 290

In the long term, however, determinacy may offer solutions for some of the nonstate actors that now oppose a harder BWC regime. For instance, while some concerns expressed by the U.S. pharmaceutical and biotech industries regarding the draft protocol may be legitimate, the experience of the U.S. chemical industry in implementing the CWC suggests that corporations can protect their business secrets and function reasonably well under a broadly similar disarmament regime if clearly stated, determinate requirements underlie applicable monitoring measures. While biological and chemical weapons present some different challenges, the

${ }^{286}$ See David P. Fidler, Constitutional Outlines of Public Health's New World Order, 77 TEMP. L. REV. 247, 267 (2004) (noting how nonstate actors performed key monitoring functions and provided accurate data on the SARS outbreak in China in 2003, eventually forcing China to deal more openly with the outbreak and causing similar embarrassment for the governments of Thailand and Indonesia).

${ }^{287}$ While transnational societal factors may contribute to the larger phenomenon of globalization or the crossnational convergence of national economic and regulatory systems, state interests continue to play a critical role, and this globalization is not proceeding evenly either across the globe or across economic sectors or other regulatory topics. See Richard H. Steinberg, Trade-Environment Negotiations in the EU, NAFTA, and WTO: Regional Trajectories of Rule Development, 91 AJIL 231, 232 (1997).

${ }^{288}$ The U.S. government's financial involvement with academic institutions in this area began in 1942 with contracts for secret work at over two dozen major U.S. universities. See Barton J. Bernstein, Origins of the Biological Warfare Program, in PREVENTING A BIOLOGICAL ARMS RACE, supra note 49, at 9, 12. By 1968, U.S. government involvement in both chemical and biological weapons programs had made such weapons "big business" for industry and higher learning. CLARKE, supra note 31, at 8. Massive increases in U.S. biodefense spending in recent years involve numerous government agencies and nonstate institutions. In the civilian biodefense sector alone, the government has dramatically increased spending since 2001. Joby Warrick, Custom-Built Pathogens Raise Bioterror Fears, WASH. POST, July 31, 2006, at A1 ("Five years after the Sept. 11 attacks, the federal government budgets nearly $\$ 8$ billion annually - an 18 -fold increase since 2001 -for the defense of civilians against biological attack.").

${ }^{289}$ Steve Charnovitz, Nongovernmental Organizations and International Law, 100 AJIL 348, 348 (2006) (noting that "[ $t$ ]oday, overwhelming NGO support for the international rule of law can no longer be assumed. NGOs follow their own stars.").

${ }^{290}$ Mahley, supra note 80 ("In our assessment, the draft Protocol would put national security and confidential business information at risk."). 
pharmaceutical industry might find determinacy in the BWC regime to be as desirable as the chemical industry and member governments have found it to be in the CWC regime. ${ }^{291}$ Nongovernmental organizations and nonstate or transnational actors that strongly support BW nonproliferation efforts may also support hard rules since they can provide these actors with a range of new strategies and facilitate enforcement actions against both governmental and nongovernmental entities. ${ }^{292}$

While transnational actors will continue to contribute to $\mathrm{BW}$ nonproliferation efforts and are likely to benefit from determinate rules in the BWC, state actors with security-driven preferences hold the key to establishing an effective ban on biological weapons. In 1972, in an attempt to achieve various short-term security objectives in the context of bipolar Cold War strategies, the most powerful state actors chose the short-term benefits and expediency of soft indeterminate provisions and soft structural approaches in designing a "hard" legally binding $\mathrm{BWC}$ regime. In the context of modern BW proliferation problems, however, these states now have a self-interested security basis for eschewing this type of soft law approach. The United States in particular has reason to reevaluate, in light of its long-term national security interests, the rejection of BWC reform policies that it embraced prior to adopting a position based on myopic interests and unilateralist sentiments. Although a soft law approach based on indeterminacy may be beneficial in other contexts, the long-term impact of its psychological and rational mechanisms in modern arms control and multilateral security instruments presents fundamental problems that pose a different research agenda.

291 See Tibor Toth, The Requirement to Strengthen the Biological and Toxin Weapons Convention, in IMPLEMENTATION OF LEGALLY BINDING MEASURES, supra note 261, at 9, 13 (arguing that the industry players involved in BWC-related activities "will need clear-cut rules of the game" and that "these companies and industrial actors would prefer clarity in the rules of the game that are applicable globally").

292 See Abbott \& Snidal, supra note 17, at 451 (private demandeurs will normally press for hard law, other things being equal, to raise the costs of violation for other parties and to facilitate enforcement against resister groups and governments, including their own). 